\title{
Uutisvuon hallitsija
}

Uutismedia kiky-kamppailussa 2015-2016

TIIVISTELMÄ Poliittisen viestinnän ja julkisuuden muutosta on kuvattu siirtymänä hybridiin mediajärjestelmään, jolle on ominaista erilaisten toimintalogiikoiden sekoittuminen ja toimijoiden välisten rajojen hämärtyminen sisältöjen loputtomassa virrassa. Tässä artikkelissa selvitetään, miten suomalainen media (STT, Helsingin Sanomat, Iltalehti ja Yle) liikutti vallan virtoja kilpailukykysopimusta koskevassa kamppailussa vuosina 2015-2016 antamalla äänen eri toimijoille. Tutkimus osoittaa, että työmarkkinakontekstissa uutisointi on mediajärjestelmän muutoksista huolimatta hyvin perinteistä. Empiria vahvistaa eliittilähteiden ylivallan ja institutionaalisten valtapositioiden merkityksen: hallitus ja ay-liike ovat kiky-uutisoinnissa selkeitä päätoimijoita, kun taas työnantajajärjestöt, oppositio ja ulkopuoliset asiantuntijat jäävät sivutoimijoiksi, eivätkä kansalaiset juuri pääse ääneen. Hybridin mediajärjestelmän vaikutuksesta voi kuitenkin nähdä viitteitä siinä, miten media antaa toimijoille äänen. Tutkimus osoittaa, että vain yhtä toimijaa lainaavat jutut (monologit) ovat paljon yleisempiä kuin kahta tai useampaa lähdettä siteeraavat jutut. Perinteisen median valta onkin uutisvuon hallinnan valtaa eli yksittäisten toimijoiden puhetekojen rytmittämistä ja kokoamista, joka ei välttämättä ole muodoltaan paljon sen dialogisempaa kuin sosiaalisen median uutisvirta. Se kuitenkin toistaiseksi kokoaa yhteen institutionaaliset valtapelurit, mikä legitimoi sen aseman keskeisenä politiikan näyttämönä. 


\section{JOHDANTO}

Vuosina 2015 ja 2016 käydyt kilpailukykysopimusneuvottelut olivat julkinen konflikti hallitusvallan ja työmarkkinavallan sekä työntekijöiden ja työnantajien välillä. Pääministeri Juha Sipilä (kesk.) käynnisti neuvottelut yhteiskuntasopimuksesta hallituksen muodostamisen ollessa kesken keväällä 2015. Hallitusohjelmassa hallitus määritteli yhteiskuntasopimuksen keskeiseksi keinoksi alentaa yksikkötyökustannuksia. Poikkeuksellista oli, kuinka hallitus asetti työmarkkinaosapuolille numeeriset tavoitteet. Työmarkkinajärjestöjen oli määrä sopia keinoista, joilla niihin päästään. Ja ellei päästäisi, hallitus asetti ehdollisia säästötoimia ja veronkorotuksia. Prosessin edetessä hallitus luopui alkuperäisestä yhteiskuntasopimus-nimityksestä, ja osapuolet neuvottelivat lopulta sovun kilpailukykysopimuksesta useiden neuvottelukierrosten jälkeen kesällä 2016.

Yhteiskuntasopimusta ja kilpailukykysopimusta koskeneita neuvotteluita voi pitää yhtenä 2000-luvun keskeisenä tapahtumaketjuna keskustelussa suomalaisesta konsensuksesta ja korporatismista (ks. esim. Rainio-Niemi 2014; Vesa ym. 2018). Työmarkkinapolitiikkaa koskeva julkinen keskustelu kohdistuu paitsi välittömään sopimusneuvotteluun tai kiistaan myös näitä syvempiin ja laajempiin yhteiskunnallisiin kysymyksiin: Kuka käyttää valtaa työmarkkinoilla? Mikä on valtion ja työmarkkinajärjestöjen suhde? Entä liittojen ja keskusjärjestöjen? Julkisen huomion kohdistuessa työmarkkinaosapuoliin nämä pyrkivät tarjoamaan kukin oman versionsa tapahtumista ja tosiasioista edistääkseen omaa asiaansa tai asemaansa yhteiskunnallisena vallankäyttäjänä. Toimittajilla on tässä "kehystyskilpailussa" merkittävä rooli (Chong ja Druckman 2013).

Aiemmissa tutkimuksissa on kiinnitetty huomiota työmarkkinapolitiikan medioitumiseen (Reunanen 2017) eli siihen, että osapuolet käyttävät mediajulkisuutta hyödykseen ja reagoivat sen tapahtumiin. Medioituminen näyttää ulottuvan julkisuuden ohella aina päätöksentekoon asti eli politiikkaverkostojen vuorovaikutukseen. Aiemmat tutkimukset ovat kuvanneet työmarkkinapolitiikkaa politiikkaverkostojen ja mediajulkisuuden välisenä dynamiikkana, jossa nämä toiminnan sfäärit ja logiikat on eroteltu selkeästi toisistaan (esim. Kunelius ym. 2010; Reunanen 2017; Reunanen ja Kunelius 2020; Reunanen ja Väliverronen 2020).

Tässä artikkelissa kahden toisistaan erillisen logiikan sijaan työmarkkinajulkisuus hahmotetaan hybridin mediajärjestelmän (Chadwick 2017) kontekstissa. Hybridille mediajärjestelmälle on ominaista erilaisten toimintalogiikoiden sekoittuminen ja toimijoiden välisten rajojen hämärtyminen sisältöjen eli tekstien, kuvan ja äänen loputtomassa virrassa. Hybridi kuvaa poliittista julkisuutta, jossa valta on niillä, jotka kykenevät luomaan, liikuttamaan ja ohjaamaan informaatiovirtoja omien tavoitteidensa mukaisesti. (Ks. Chadwick 2017; Witschge ym. 2019.) Siksi tässä tutkimuksessa huomio keskittyy näihin vallan virtauksiin vuosien 2015 ja 2016 kilpailukykysopimusprosessin aikana. Artikkelissa selvitetään empiirisesti, kuka tai ketkä pääsevät perinteisessä mediassa ääneen kilpailukykysopimuksen uutisoinnissa.

Ääneen pääsemisen käsite liittyy median ja politiikan tutkimuksen kentässä kysymyksiin demokratiasta, edustuksellisuudesta ja julkisuuden moniäänisyydestä (Brown ym. 1987; Couldry 2006; 2008; Richardson 2006; Sjøvaag ja Pedersen 2018). Tässä tutkimuksessa ääneen pääsemisellä tarkoitetaan sitä, että tulee siteeratuksi ja näin ollen saa sanomansa läpi tai tulee vähintäänkin kuulluksi mediassa. Lähtöoletuksena on, että ääneen pääseminen on median demokratiatehtävän kannalta tärkeä kysymys, koska siteeratut toimijat kykenevät kohdistamaan huomiota ja vaikuttamaan vallan virtoihin. Samalla heidät tunnustetaan legitiimeinä keskustelijoina ja vallan virtojen liikuttajina. 
On myös olennaista selvittää, millä tavalla ja missä positiossa äänessä olevat toimijat suhteessa toisiinsa ovat. Ääneen pääsemistä koskevalla empiirisellä analyysillä konkretisoimme sitä, miten media jäsentää vallan virtoja sekä organisoi ja jäsentää toimijoiden välistä vuorovaikutusta.

\section{VALLAN VIRTAUKSET JA UUTISVUO}

Viestintäteknologian nopea kehitys ja leviäminen ovat muokanneet koko informaatioympäristöä. Tiedontuotannon paikat ja välineet ovat muuttuneet voimakkaasti, mikä on johtanut valtasiirtymiin ja yhteiskunnallisiin murroksiin. Internet ja sosiaalinen media ovat raivanneet tilaa perinteiseltä journalistiselta medialta - analogisen ajan portinvartijalta. (Ks. Bennett ja Iyengar 2008; Bennett ja Pfetsch 2018; Gonzalez-Bailón 2017.) Valtasiirtymä on ollut merkittävä, mutta toistaiseksi vain osittainen. Maailmassa, jossa mikään yksi taho ei hallitse merkitysten rakentumista, journalistisen median juttuja voidaan tarkastella esimerkiksi osana yhteistoiminnallista kertomisen prosessia (Papacharissi 2015; 2016) tai suhteessa sosiaalisen median verkostologiikkaan (ks. Klinger ja Svensson 2015; Skogerbø ja Kunelius 2017; Wihbey 2019), minkä ohella uutismedia voidaan ymmärtää itsenäisenä toimijana, jolla on oma, tunnistettava perinteensä. Perinteiset joukkoviestimet muodostavat Michael Schudsonin (2020, 92-93) mukaan edelleen uutistuotannon ytimen, josta sisällöt kiertävät eri puolille. Uutismedia on osa hybridiä mediajärjestelmää, mutta omanlaisensa informaatiovirtojen luoja, liikuttaja ja ohjaaja.

Hybridin mediajärjestelmän voi hahmottaa alustojen, sisällön ja toimijoiden sidostamana verkostona, jossa perinteisen journalistisen median tehtävänä on edelleen asettaa suuria määriä ihmisiä keskinäisiin kosketuksiin ja kanssakäymiseen (ks. Pietilä 2012, 298-299; Pietilä ja Sondermann 1994, 38, 46). Kyse on ajankohtaisten, tosiasiapohjaisten ja yhteisöllisesti merkityksellisten esitysten kokoamisesta, muokkaamisesta, esittämisestä ja välittämisestä (ks. Luostarinen 2002, 28; Schudson 2003, 67-69). Empiiriset tutkimukset osoittavat, että journalistinen media on poliittiselle viestinnälle merkityksellinen myös muuttuneessa, hybridissä mediajärjestelmässä (Shehata ja Strömbäck 2013; Skogerbø ja Krumsvik 2015; Vonbun ym. 2016). Perinteisellä medialla on merkitystä muun muassa huomion kohdentamisessa (Goel ym. 2016) sekä verkon ja sosiaalisen median keskustelujen kiihdyttäjänä (King ym. 2017). Perinteisen median ja alustojen vuorovaikutusta tutkinut Gary King kollegoineen (2017) sekä pitkittäistutkimuksella perinteisen median agendavaltaa tutkineet Monika Djerf-Pierre ja Adam Shebata (2017) korostavat perinteisen median agendan määrittämisen vallan olevan edelleen huomattava. John Wihbey $(2019,19)$ painottaa, että juuri verkoston keskeisenä solmukohtana uutismedia tulee olemaan jatkossakin merkittävä toimija.

Informaatioympäristön murros on tuonut mukanaan uusia käsitteitä, joilla kuvata sisältöjen leviämistä ja kuluttamista. Viraalisuuden ja tarttuvuuden käsitteiden (ks. Jenkins ym. 2013; Sampson 2012) ohella erilaiset kiertoon (cycle, circulation) tai virtaukseen (flow) viittaavat käsitteet ovat tulleet tutuiksi. Tässä artikkelissa päähuomio on vallan virtauksissa, joita tutkitaan ensisijaisesti perinteisen median uutisoinnin pohjalta. Tämä perustuu yhtäältä Andrew Chadwickin (2017) ajatukseen virtauksista hybridin mediajärjestelmän keskeisenä ominaispiirteenä, toisaalta Manuel Castellsin (2009) teesiin viestintäverkostoista keskeisenä yhteiskunnallisen vallankäytön kanavana. 
Journalistinen valta on ennen kaikkea medialogiikan (ks. Eide 2007) hallinnan valtaa. Perinteinen media ei hallitse enää yksiselitteisesti sitä mistä puhutaan ja yhä vähemmän sitä miten puhutaan, mutta se edelleen valitsee omissa julkaisuissaan ääneen pääsevät henkilöt ja toimijat, asettaa nämä suhteessa toisiinsa (casting) sekä säätelee puheenvuoroja ja käsiteltävien aiheiden painoarvoa. Media ei ole ainoastaan vallankäytön areena, vaan aktiivinen toimija, joka vaikuttaa niin julkisen keskustelun sisältöön kuin päätöksentekoon. Tiedotusvälineet eivät ehkä kykene käyttämään suoraa valtaa muihin toimijoihin (ks. Dahl 1957), mutta liikutellessaan vallan virtoja ja antaessaan tietyille toimijoille äänen ne vaikuttavat tarjolla oleviin vaihtoehtoihin, asenteisiin ja arvoihin sekä puhetapoihin ja diskursseihin (ks. Bachrach ja Baratz 1962; Fairclough 1992; Lukes 2005).

Chadwickin (2017) ja Castellsin (2009) teesejä soveltaen artikkelissa tutkitaan kiky-uutisoinnin muodostamaa uutisvuota, jossa vallan virtaukset tulevat näkyviksi. Uutisvuo on rajattua tai kontrolloitua uutissykliä hallitsemattomampi voima, johon vaikuttavat journalistisen median ohella sosiaalinen media, PR-koneistot ja politiikan ammattilaiset sekä ei-ammattimaiset toimijat. Kikyn kaltaisissa yhteiskunnallisissa uutisissa tai pitkittyneissä uutistapahtumissa (ks. Hachten 2005, xvi) useat eri toimijat osallistuvat kokonaisuuteen, jossa sekoittuvat paitsi eri journalismin lajit myös sosiaalisen median keskustelut. Kiky-prosessille oli ominaista, että tapahtumat ja niiden uutisointi elivät vuoden aikana, minkä vuoksi tämän tutkimuksen kiinnostus kohdistuu sekä hetkessä että ajallisesti tapahtuvaan vallan virtojen liikutteluun.

Bill Kovach ja Tom Rosenstiel $(2014,58)$ kirjoittavat, että käytännön totuus on journalismissa usein muuntautumiskykyinen siinä mielessä, että se kasvaa kuin tippukivi luolassa. Uudet näkökulmat ja tiedot, kontekstia rakentavat huomiot ja aiheen ympärille syntyvä keskustelu rakentavat kaikki uusia tulkinnan tasoja. Käsite uutisvuo pyrkii tavoittamaan uutisoinnin liikkeen ja voiman muutokset, kun huomio on juuri kikyä koskevissa jutuissa neljästä eri mediasta. Uutisvuo-käsitteen tarkoituksena on tavoittaa uutisoinnin rytmi eli se, miten ja missä vaiheessa eri toimijat pääsevät ääneen uutisvuon virratessa. Kokonaisaineisto antaa uutisoinnista välttämättömän kokonaiskuvan, mutta tarkemmat aineistohuomiot paljastavat nyansseja vallan virtauksissa.

Kiky-prosessissa oli mediatapahtumalle ominaisia dramaattisia käännekohtia ja temaattista kantavuutta (ks. Hepp ja Couldry 2010, 12), vaikka sitä ei voi pitää perinteisessä mielessä mediatapahtumana (ks. Dayan ja Katz 1992, 5-9), sillä se ei kokonaisuutena ollut seremoniallinen poikkeus median jokapäiväiseen virtaan. Pikemminkin voi sanoa, että journalismin valta ja vallan virtaukset tulevat näkyviksi välittömän uutisoinnin ja sitä seuranneiden juttujen kierrossa. Medialla on vaikutusta vallan virtoihin huomion suuntaamisen ja agendan asettamisen (suhde muihin toimijoihin ja yleisöön) ohella myös tunnistettavan ja tunnustetun muotonsa (miten) ja sisällön vuoksi (mitä). Mediatapahtumia voi katsoa myös ajallisuuden kautta, kuten Barbie Zelizer $(2018,137)$ huomauttaa: "Kierron tavasta tai luonteesta riippumatta yleinen representaatio tuo esiin ajalliset impulssit - jatkuvuuden ja epäjatkuvuuden, lineaarisuuden ja samanaikaisuuden, kiihdytyksen ja pysähdyksen, keston ja rytmin, toiston ja tempon, jotka tuottavat ajassa rakentuvia luonnosmaisia ja kaavamaisia kuvauksia." 


\section{TUTKIMUSONGELMAN MÄÄRITTELY}

Tässä artikkelissa huomion keskipisteessä on journalistisen median rooli aktiivisena toimijana, tapahtumien kertojana ja äänen antajana. Tutkimusongelmana on, miten media liikutti vallan virtoja antamalla äänen eri toimijoille kiky-kamppailussa vuosina 2015-2016. Tähän vastataan selvittämällä laajan media-aineiston pohjalta kolmen tasoisia empiirisiä alakysymyksiä. Kysymyksiä lähestytään ensisijaisesti määrällisesti, mutta määrällistä analyysia tukee aina myös laadullinen analyysi.

Analyysin ensimmäinen taso koskee median valtaa esittää ja antaa ääni:

1) Kuka tai ketkä pääsivät ääneen kiky-kamppailussa? Tutkimalla kamppailun pää- ja sivutoimijoita sekä nimeämällä mediassa eniten esiintyvät henkilöt paljastuu kenelle media antaa äänen ja kenen yli mahdollisesti puhutaan.

Analyysin toisella tasolla kiinnitetään huomiota median lähteisiin ja äänen antamiseen liittyviin kysymyksiin, jotka kiinnittyvät paitsi esittämiseen myös median muotokieleen ja vallan virtauksiin. Huomio kohdistetaan erityisesti median tapaan hyödyntää suoria ja epäsuoria lainauksia kiky-prosessin eri vaiheissa.

2) Miten eri toimijat on asetettu dialogiin tai keskusteluyhteyteen toisten toimijoiden kanssa? Tutkimalla siteerattuja lähteitä voidaan hahmottaa, miten uutisointi muokkaa tapoja ymmärtää kiky-kamppailun osapuolet suhteessa toisiinsa. Samalla tarkastellaan sitä, miten yhden, kahden tai useamman siteeratun lähteen jutut rytmittävät uutisointia.

Analyysin kolmannella tasolla tarkastellaan kiky-kamppailun keskeisten toimijoiden lähettämiä tiedotteita ja niiden läpäisevyyttä sekä siteerattuja sosiaalisen median päivityksiä mediateksteissä. Tämä mahdollistaa vallan virtausten tarkastelun sisällön kierron näkökulmasta.

3) Miten kamppailun osapuolet saavat äänensä esiin julkisilla puheenvuoroillaan? Tutkimalla eri osapuolten lähettämiä tiedotteita ja niiden läpäisevyyttä sekä sosiaalisen median lainauksia mediateksteissä sivutaan sosiaalisen median ja perinteisen median vuorovaikutusta ja uutismedian roolia vallan virtojen ohjaajana.

Tutkimuksen katse on perinteisestä mediasta kohti hybridiä mediajärjestelmää, jolloin tarkoituksena on luoda pohjaa tutkimukselle virtausten ja median julkaisulogiikan eroista, yhtäläisyyksistä ja mahdollisesta yhteenkietoutumisesta. Artikkelimme empiiriset osakysymykset osoittavat, kuinka tutkimusasetelman keskiössä on juuri perinteinen journalistinen media ja sen kyky vaikuttaa uutisvuon virtauksiin. Aineisto mahdollistaa journalismin voiman ja ominaispiirteiden hahmottamisen kiky-keskustelun ytimessä, mutta esimerkiksi sosiaalisen median kyky vaikuttaa virtauksiin jää välttämättä pohdinnan tasolle. 


\section{TUTKIMUKSEN AINEISTO JA MENETELMÄT}

Tutkimuksemme pääaineisto koostuu kilpailukykysopimusta käsittelevästä media-aineistosta, johon sisältyvät Ylen ( $\mathrm{N}=1$ 137), Helsingin Sanomien ( $=1171)$, STT:n ( $=835)$ ja Iltalehden $(\mathrm{N}=1012)$ koneellisesti tunnistetut, aihetta käsittelevät jutut vuosilta 2015 ja 2016. Tilastolliset analyysimme perustuvat tähän aineistoon. Tutkimuksen laadullisessa osassa aineistoa on täydennetty Yleisradion uutis- ja ajankohtaisohjelmien metatiedoilla, joista on koottu kiky-jutuissa ja -keskusteluissa haastatellut henkilöt. Lisäksi laadullisessa analyysissa on käytetty samalta ajanjaksolta Akavan (11), Elinkeinoelämän keskusliiton (5), Kuntatyönantajien (6), SAK:n (32), STTK:n (9), Suomen Yrittäjien (27) ja Valtioneuvoston (5) lehdistötiedotteita. Tiedotemateriaali ei siis kata kiky-kamppailun toimijoista yhtä keskeistä ryhmää eli poliittisia puolueita, mutta rajallisena otoksena se toimii tukena pääaineistolle.

Vuoden mittainen kilpailukykysopimukseen liittynyt työmarkkinakiista sisälsi useita kriisipisteitä, joissa neuvottelut keskeytyivät ja käynnistyivät uudelleen. Nämä tunnistettavat kriisipisteet näkyvät tutkimuksen aineistossa uutistihentyminä (ks. Vainikka ym. 2020). Osana vallan virtausten analyysiä aineistoa on rajattu tämän artikkelin tarpeisiin ja laadullisten huomioiden mahdollistamiseksi keskittymällä viiteen keskustelun tihentymään, jotka antavat kokonaisuutta tarkemman näkymän uutisoinnin sykliin ja vallan virtauksiin. Tihentymät on tunnistettu aineistosta koneellisesti. Kyse ei ole yksiselitteisesti uutisoinnin viidestä intensiivisimmästä kohdasta, vaan valinnassa yhtenä kriteerinä on ollut tihentymien temaattinen ja ajallinen kattavuus. Tihentymät edustavat koko pitkää tapahtumasarjaa ja sen erilaisia vaiheita. Näin ollen tunnistettavista huipuista on jätetty ulkopuolelle esimerkiksi uutisoinniltaan intensiivinen neuvotteluiden toinen kariutuminen 20.8.2015. Aineistosta tunnistetut tihentymät ovat:

- Ensimmäisten neuvotteluiden epäonnistuminen 4.-14.5.2015

- Niin sanottujen pakkolakien esittely 6.-20.9.2015

- Sopimuksen kaatuminen neljännen kerran 26.11-6.12.2015

- Neuvotteluiden onnistumisen läheltä piti -tilanne 27.2.-8.3.2016

- Neuvotteluiden lopullinen onnistuminen 25.5.-14.6.2016 


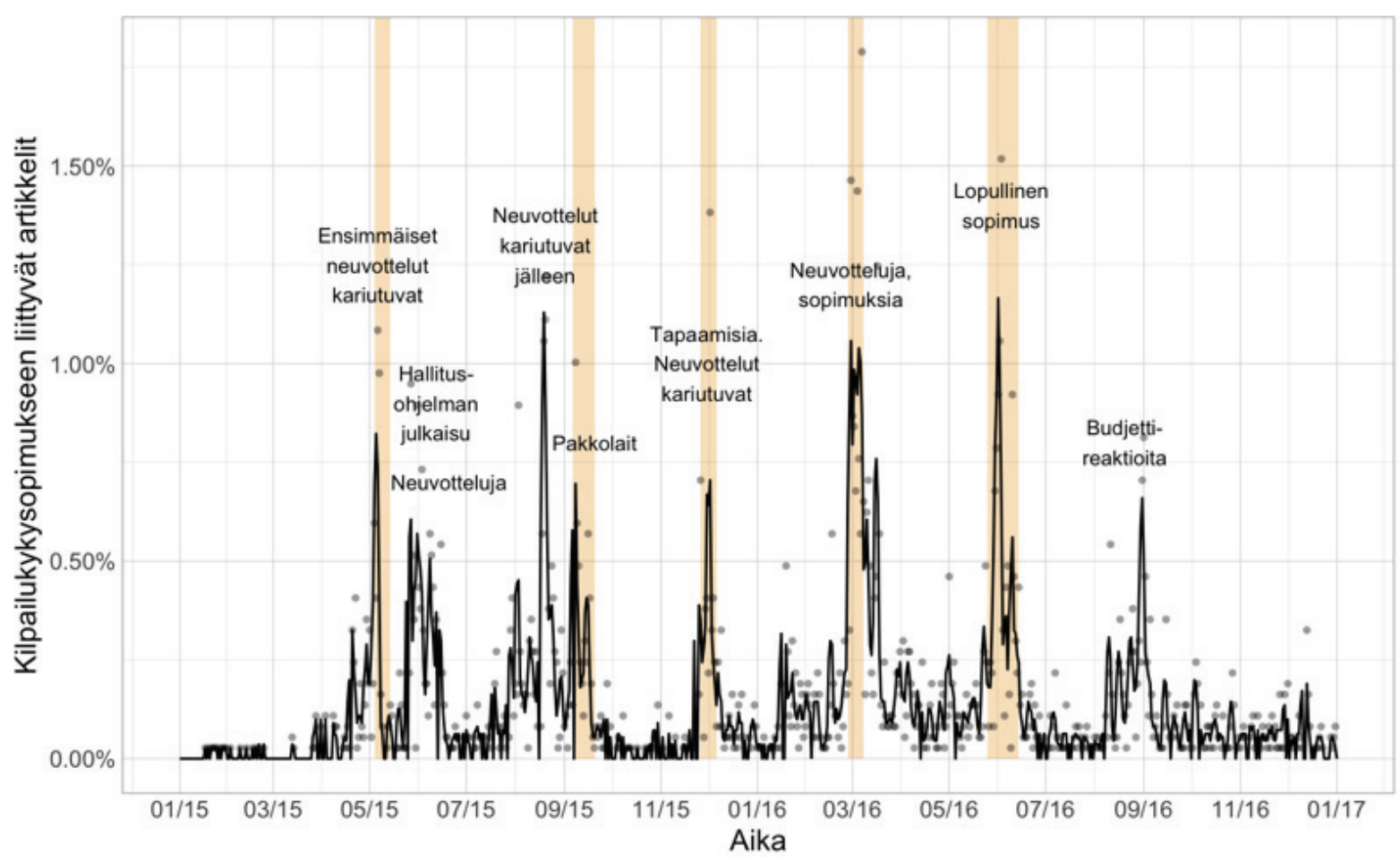

Kuvio 1. Kilpailukykysopimusta käsittelevien artikkelien ajallinen jakautuminen

Selite: Viisi tutkittua keskustelun tihentymää on merkitty kuvaan. Pisteet kuvaavat yksittäisten päivien artikkelimääriä, kun taas viivakuvaaja piirtää näistä kolmen päivän liukuvalla keskiarvolla tasoitetun version.

Tutkimuksemme yhdistää automatisoidun laskennallisen analyysin, jossa tutkittava ilmiö voidaan paikantaa suuresta määrästä tekstiä koneellisesti, laadulliseen lähilukuun, jonka avulla pystyimme pureutumaan journalismin sisältöihin yksittäisten juttujen ja rajattujen aineistokokonaisuuksien tasolla. Pääanalyysimme kohdistuu aineistossa esiintyviin lainauksiin ja niiden esittäjiin. Tätä varten aineistosta tunnistettiin automaattisesti sekä suoria että epäsuoria ("[toimija]n mukaan [lainaus]", "[toimija] arvioi että [lainaus]", "[lainaus], [toimija] painottaa") lainauksia ja niiden esittäjiä syntaksipohjaisia sääntöjä hyödyntäen. ${ }^{1}$ Lainausten tunnistuksen oikeellisuutta arvioitiin F1-pisteytyksellä, joka oli noin 77 prosenttia. Useimmin lainauksissa esiintyvät noin 300 puhujaa (73 \% lainauksista) luokiteltiin jokainen yhteen seuraavista ryhmistä: "hallitus", "ammattiyhdistys", "oppositio", "työnantajajärjestö" ja "muut". Rajaus keskittää voimasuhdeanalyysin aineistossa usein esiintyviin toimijoihin, jotka toistuvalla esiintymisellään henkilöivät keskustelua ja edustamiaan ryhmiä. Artikkelit luokiteltiin "monologeiksi", "dialogeiksi" ja "polylogeiksi" sen mukaan, kuinka monta yllä olevista ryhmistä oli edustettuna artikkelin lainausten puhujissa.

Monologeista, dialogeista ja polylogeista poimittiin lähempään tarkasteluun uutistihentymien aikana julkaistut jutut. Monologien tarkastelua jatkettiin ottamalla lähilukuun tihentymistä 1, 2 ja 
4 yksittäiset päivät, jolloin monologeja oli julkaistu eniten (6.5.2015, 8.9.2015 ja 4.3.2016). Näiden monologien avulla rakennettiin tyypittely, jonka pääkategoriat olivat monologit (viisi tarkentavaa alakategoriaa) ja ei-ihan-monologit (kaksi tarkentavaa alakategoriaa). Koneellisesti tunnistettujen monologien joukossa on siis myös joitakin juttuja, joissa on lainattu suoraan yhtä lähdettä, mutta muiden osapuolien näkökantoja on myös tuotu esiin ilman, että tämä määrittyisi koneellisesti tunnistettavaksi lainaukseksi. Koneellisesti tunnistetuista dialogeista ja polylogeista valittiin yhteisanalyysiin yhteensä 40 juttua, neljä kutakin juttutyyppiä jokaisesta viidestä tihentymästä. Tätä aineistoa luettiin kolmen tyypittelyä tukevan kysymyksen kautta: millainen journalistinen teksti oli kyseessä, millainen rooli sitaateilla oli jutun retorisessa kokonaisuudessa ja miten henkilöt tai toimijat oli jutussa kuvattu ja asemoitu suhteessa toisiinsa.

Lehdistötiedotteita hyödynnettiin osana tiedotteiden kierron tarkastelua ääneen pääsemisen näkökulmasta. Pohjana toimi koneellinen tekstin uudelleen käytön tunnistaminen ${ }^{2}$ (ks. Vainikka ym. 2020). Tihentymiä tutkittiin muun muassa sen kautta, ketkä saivat ja missä medioissa oman kantansa kuuluviin (laskennallinen vertailu) ja miten tiedotteissa käytetyn kielen värikkyys heijastui tiedotteiden saamaan näkyvyyteen (laadullinen lähiluku).

\section{KANSALAISET SEURAAVAT SIVUSTA, KUN HALLITUKSEN MIEHET PUHUVAT}

Perinteisessä mediassa vallan virrat näkyvät ilmeisimmin siinä, ketkä pääsevät ääneen, millaisessa positiossa ja miten itsenäisesti. Hybridissä mediajärjestelmässä journalistinen media on yksi poliittisen julkisuuden keskeinen näyttämö, jossa toimijat pyrkivät ääneen, kohtaavat ja käyvät keskustelua. Poliittisen viestinnän tutkimuksessa on selvitetty esimerkiksi agendan asettamisen valtaa, joskin huomiota on kiinnitetty myös kykyyn kehystää tai vaikuttaa juttujen sävyyn (ks. van Aelst ja Walgrave 2011; Boydstun 2013; Entman 2007; McCombs 2014; Walgrave ja van Aelst 2006). Samoin on voitu huomioida, kuinka julkisuudessa esiintyessään politiikan osapuolet vetoavat erilaisiin legitimaatioperustoihin ja voivat näin vahvistaa tai horjuttaa omaa tai toisten osapuolten legitimaatiota ja vaikutusvaltaa varsinaisissa päätöksentekotilanteissa (Reunanen 2017; Reunanen ja Kunelius 2019).

Tämän tutkimuksen perusteella vuosien 2015-2016 kiky-kamppailun asetelma suomalaisessa mediassa oli selkeä. Jokaisessa tutkitussa mediassa eli STT:llä, Yleisradiossa, Helsingin Sanomissa (HS) ja Iltalehdessä (IL) eniten äänessä olivat hallitustoimijat ja ammattiyhdistystoimijat (ks. Kuvio 2). Hallitusta ja ay-liikettä voikin pitää kiky-keskustelun päätoimijoina. Nämä ryhmät olivat äänessä yli puolessa tutkittujen kikyä käsitelleiden juttujen suorista ja epäsuorista lainauksista. Sen sijaan oppositio ja työnantajajärjestöt jäivät sivutoimijoiksi. Samoin näiden neljän pääkategorian ulkopuolelle jäävät "muut" eli erilaiset asiantuntijat ja ulkopuoliset kommentaattorit olivat kamppailun sivutoimijoita. 


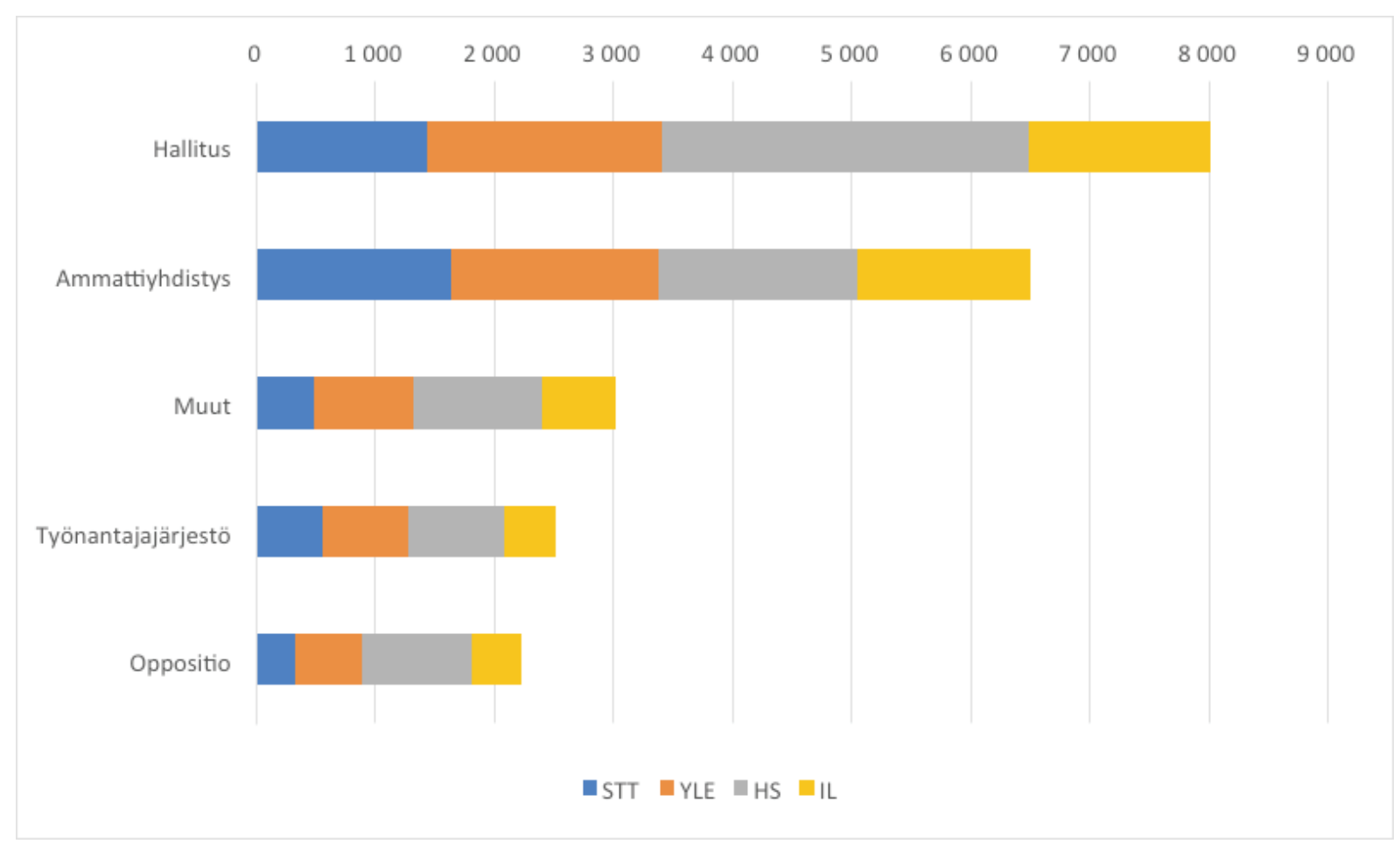

Kuvio 2. Suorat ja epäsuorat lainaukset toimijaryhmien mukaan lajiteltuina STT:n, Yleisradion, Helsingin Sanomien ja Iltalehden kiky-jutuissa 2015-2016

Tulos on linjassa aiemman tutkimuksen kanssa. Esa Reunanen ja Jari Väliverronen (2020, 84-85) ovat tutkineet, kuinka kolmessa eri vuosikymmenten keskeisessä työmarkkinakamppailussa eri toimijat ovat päässeet puhumaan Helsingin Sanomissa. Heidän havaintonsa mukaan 1960-luvun lopun työmarkkinapolitiikka ensimmäisen varsinaisen tulopoliittisen sopimuksen (Liinamaa 1) solmimisen aikaan oli vähemmän julkista kuin nykyisin. Työmarkkinoiden edustajien osuus juttujen puhuvista toimijoista on selvästi pienempi Liinamaa 1:n tapauksessa kuin vuosina 1991 Esko Ahon (kesk.) ja 2015 Juha Sipilän ajamien työmarkkinareformien kohdalla. Tutkimuksen otokset ovat selvästi tätä artikkelia pienempiä, mutta yleiskuva on selkeä: vuosina 1991 ja 2015 päätoimijoina mediassa ovat olleet juuri hallitus ja ammattiyhdistysliike.

Helsingin Sanomat erottuu tämän artikkelin aineistossa eri medioiden välisessä tarkastelussa siinä, miten usein juuri hallitus on päässyt lehden kiky-jutuissa ääneen (ks. Kuvio 3). HS:ssa hallitus on äänessä yli 40 prosentissa kaikista lainauksista. Eroa korostaa se, että ammattiyhdistysliikkeen edustajat ovat lehdessä myös selvästi vähemmän äänessä kuin muissa tutkituissa medioissa. Tekemämme Pearsonin khiin neliötesti osoittaa erojen olevan tilastollisesti merkitseviä ( $\mathrm{p}$-arvo $<0.001$ ). HS antoi siis vuosina 2015-2016 kiky-uutisoinnissaan äänen muita useammin juuri hallitukselle, eikä lainannut yhtä paljon ammattiliittojen edustajia kuin muut tutkitut mediat. Sen sijaan STT lainasi suoraan tai epäsuorasti merkitsevästi muita enemmän ay-liikkeen edustajia. 


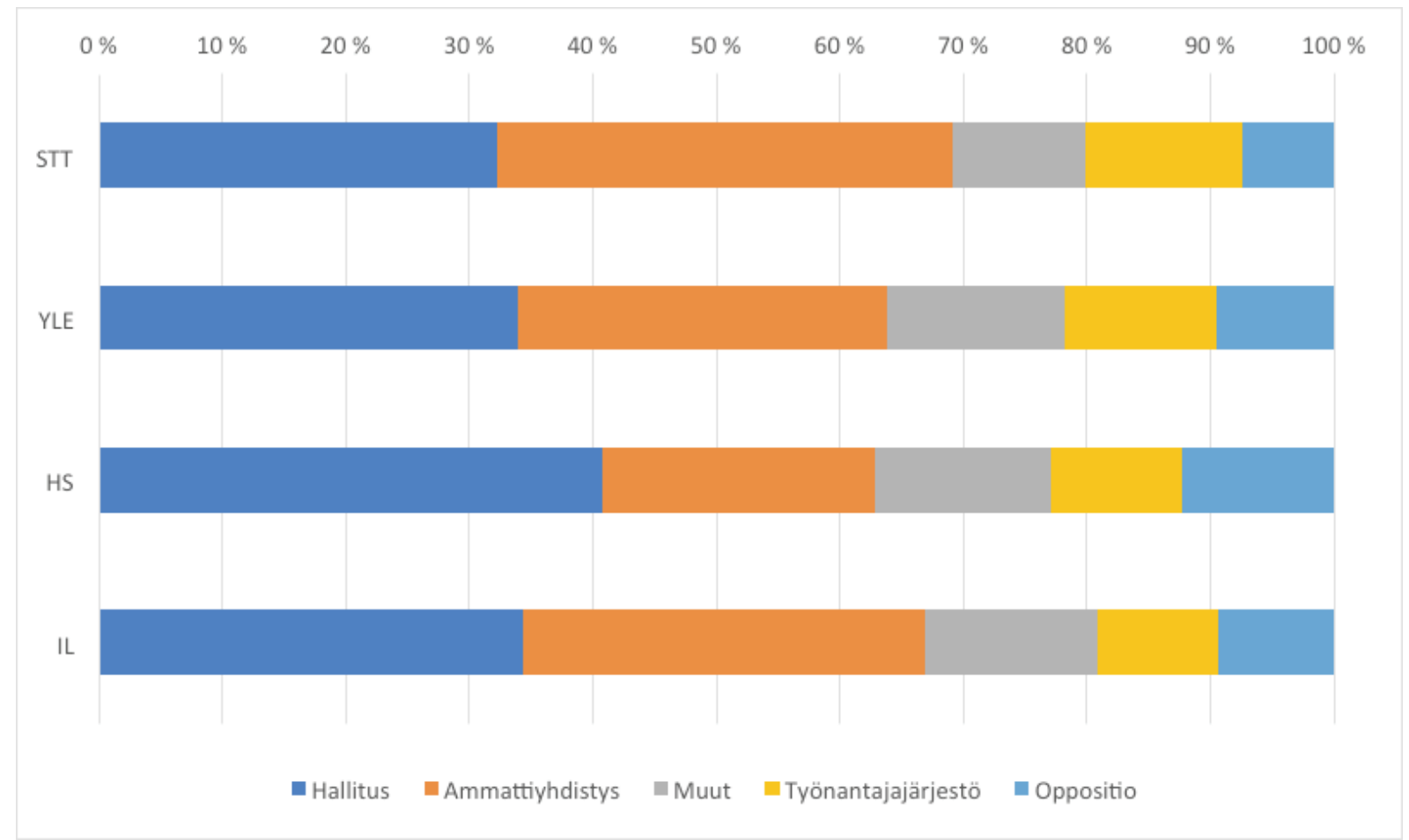

Kuvio 3. Toimijaryhmien osuudet suorista ja epäsuorista lainauksista STT:n, Yleisradion, Helsingin Sanomien ja Iltalehden kiky-jutuissa 2015-2016

Vuosien 1991 ja 2015 työmarkkinakamppailuita värittää asetelma, jossa porvarihallituksen pääministeri on ajanut työmarkkinauudistuksia. Näin ollen mediassa ääneen pääsevät korostetusti juuri hallituksen edustajat ja työntekijöitä edustavat ammattiyhdistystoimijat. Kiky-prosessin pääministerikeskeisyys näkyy myös siinä, keitä henkilöitä lainataan eniten suoraan tai epäsuoraan. Pääministeri Juha Sipilä on jokaisessa tutkitussa mediassa ollut kiky-kamppailun siteeratuin lähde (ks. Taulukko 1). Kamppailu henkilöityi siinä määrin Sipilään, että häntä siteerattiin useammin kuin hallituskumppaneiden edustajia Alexander Stubbia (kok.), Petteri Orpoa (kok.), Timo Soinia (ps.), Jari Lindströmiä (ps.), Matti Vanhasta (kesk.) ja Olli Rehniä (kesk.) yhteensä. 
Taulukko 1. 20 eniten suoraan tai epäsuoraan lainattua henkilöä STT:n, Yleisradion, Helsingin Sanomien ja Iltalehden kiky-jutuissa 2015-2016

\begin{tabular}{|c|c|c|c|c|c|c|c|}
\hline & Toimija & Ryhmä & STT & YLE & HS & IL & Yhteensä \\
\hline 1. & Juha Sipilä & Hallitus (kesk.) & 622 & 618 & 997 & 691 & 2928 \\
\hline 2. & Lauri Lyly & AY (SAK) & 391 & 408 & 427 & 367 & 1593 \\
\hline 3. & Alexander Stubb & Hallitus (kok.) & 135 & 220 & 386 & 140 & 881 \\
\hline 4. & Antti Palola & AY (STTK) & 257 & 161 & 216 & 157 & 791 \\
\hline 5. & Antti Rinne & Oppositio (sd.) & 166 & 161 & 297 & 127 & 751 \\
\hline 6. & Jyri Häkämies & TA (EK) & 210 & 193 & 194 & 150 & 747 \\
\hline 7. & Petteri Orpo & Hallitus (kok.) & 112 & 83 & 353 & 78 & 626 \\
\hline 8. & Sture Fjäder & AY (Akava) & 197 & 104 & 103 & 80 & 484 \\
\hline 9. & Timo Soini & Hallitus (ps.) & 96 & 122 & 173 & 92 & 483 \\
\hline 10. & Riku Aalto & AY (Metalliliitto) & 104 & 140 & 124 & 82 & 450 \\
\hline 11. & Jari Lindström & Hallitus (ps.) & 97 & 102 & 130 & 93 & 422 \\
\hline 12. & Ann Selin & AY (PAM) & 113 & 97 & 83 & 110 & 403 \\
\hline 13. & Marko Piirainen & AY (AKT) & 95 & 91 & 87 & 113 & 386 \\
\hline 14. & Jarkko Eloranta & AY (JHL/SAK) & 98 & 55 & 63 & 52 & 268 \\
\hline 15. & Matti Vanhanen & Hallitus (kesk.) & 45 & 64 & 115 & 21 & 245 \\
\hline 16. & Matti Alahuhta & TA (EK) & 33 & 35 & 125 & 28 & 221 \\
\hline 17. & Olli Rehn & Hallitus (kesk.) & 48 & 59 & 68 & 35 & 210 \\
\hline 18. & Li Andersson & Oppositio (vas.) & 18 & 75 & 83 & 33 & 209 \\
\hline 19. & Ville Niinistö & Oppositio (vihr.) & 37 & 41 & 96 & 29 & 203 \\
\hline 20. & Paavo Arhinmäki & Oppositio (vas.) & 30 & 45 & 83 & 44 & 202 \\
\hline
\end{tabular}

Taulukko 1 ja siinä mainitut kiky-kamppailun eniten ääneen päässeet henkilöt kuvastavat hyvin kiky-kamppailun institutionaalista asetelmaa. Listalla on seitsemän hallituksen edustajaa kaikista kolmesta hallituspuolueesta, neljä opposition edustajaa kolmesta eri puolueesta, seitsemän ammattiliittojen edustajaa ja kaksi työnantajien edustajaa. Kiinnostavaa on, kuinka työnantajapuolelta eniten äänessä olivat EK:ta edustaneet toimitusjohtaja Jyri Häkämies ja puheenjohtaja Matti Alahuhta. AY-liikkeestä äänessä olivat seitsemän eri liiton puheenjohtajat, joista tosin JHL:n puheenjohtaja Jarkko Eloranta siirtyi SAK:n puheenjohtajaksi kiky-sopimuksen solmimisen jälkeen kesällä 2016. Sen sijaan kuviosta 3 hahmottuu hyvin, miten eri toimijaryhmät 
ovat päässeet tutkituissa medioissa ääneen suorien ja epäsuorien lainauksien muodossa. Tutkimuksen aineisto osoittaa, kuinka kamppailu mediassa käytiin ensisijaisesti hallituksen ja ayliikkeen välillä sekä jonkin verran keskusjärjestöjen SAK:n ja EK:n välillä, mutta ei niinkään liittotasolla, jossa sopimukset kuitenkin lopulta hyväksyttiin.

Toinen ilmeinen havainto koskee ääneen päässeiden sukupuolta. Kahdenkymmenen eniten ääneen päässeen joukossa on vain kaksi naista, Palvelualojen ammattiliitto PAM:n puheenjohtaja Ann Selin ja Vasemmistoliiton puheenjohtajaksi kesällä 2016 noussut Li Andersson. Neuvotteluiden miesvaltaisuus nousi keskustelun aiheeksi jo vuonna 2015, ja esimerkiksi Helsingin Sanomien Nyt-toimitus kirjoitti aiheesta sarkastisesti otsikoidun jutun: "Juha esitteli yhteiskuntasopimustaan Alexanderille, Jyrille, Markulle, Jarille, Juhanille, Laurille, Antille ja Sturelle (taustalla Paula)" (HS 3.8.2015). Kiky-neuvotteluiden sukupuolirakenne oli hyvin miehinen, sillä jokaisen hallituspuolueen keskeisillä paikoilla oli miehiä ja samoin useiden ammattiliittojen puheenjohtajana oli tuolla hetkellä mies.

Kiky-neuvotteluiden edetessä todettiin moneen kertaan, että prosessin aikana esitetyt uudistukset osuvat juuri naisvaltaisiin aloihin julkisella sektorilla. Esimerkiksi SAK:n Lauri Lyly totesi hallituksen leikkausehdotuksista: "Nämä toimet tulevat palkansaajien maksettavaksi, erityisesti naisten" (HS 9.9.2015). STTK:n Antti Palola muistutti, kuinka suomalaiset julkiset hyvinvointipalvelut ovat naisten harteilla: "Heidän työehtojensa heikentäminen merkitsee, että tasa-arvo on hallitukselle vain sanahelinää." (IL 8.9.2015.) Myöhemmin on myös todettu, että juuri sotehallinnossa ja julkisissa palveluissa toimivien työaika piteni (Taskinen 2019). Tässä artikkelissa tutkitut mediat vahvistivat entisestään asetelmaa, jossa päätoimijoita ovat päättävissä asemissa olevat miehet, mutta toimenpiteet osuvat myös naisiin ja erityisesti naisvaltaisiin aloihin. Pienet ja keskituloiset naiset mainitaan uutisoinnissa, ja esimerkiksi kätilöt pääsivät hetkeksi parrasvaloihin (ks. Yle A-studio 16.9.2015; Yle.fi 28.9.2015), mutta pääosin heidän yli puhutaan.

Sukupuolen ja ääneen pääsemisen näkökulmasta kiinnostava yksityiskohta oli pääministeri Juha Sipilän yksittäistä mediatapahtumaa muistuttava tv-puhe (16.9.2015) ja sitä seuranneet käänteet. Kaksi kätilöä kertoi pääministerin puheen jälkeen Ylen A-studiossa, miten sunnuntailisien leikkaukset olisivat vaikuttaneet heidän palkkaansa. He toivat esiin myös mahdollisuuden korvata ilta- ja sunnuntailisiin kohdistuvat leikkaukset lomarahaleikkauksilla. Hallitus pyörsi päätöksiään, ja syyskuussa uudessa A-studion haastattelussa (Yle.fi 28.9.2015) pääministeri Juha Sipilä kertoi, kuinka juuri kätilöt käänsivät hänen päänsä. Pääministeri totesi: "A-studion kätilöiden haastattelu oli puhutteleva ja sai minutkin vielä kerran miettimään, että eiköhän tähän löytyisi kuitenkin keino ja niin se löytyi." (Emt.) Kätilöiden ja muiden julkisen sektorin naisvaltaisten alojen tilanteesta olivat kertoneet niin oppositio, ay-liike kuin tutkijatkin (ks. Elomäki ym. 2016), mutta vasta tv-puheen ansiosta kätilöille avautunut mahdollisuus esittää suora vetoomus pääministerille vaikutti politiikkaan. Miikaeli Kylä-Laaso $(2019,52)$ huomioi gradussaan, miten kätilöiden arkinen puhe huolistaan yksilöinä ja kansalaisina antoi legitimiteetin julkisen sektorin pienipalkkaiselle naiselle. Ay-liikkeen esittämällä vastaavalla kritiikillä ei ollut samaa vaikutusta hallituksen silmissä.

Ääneen pääsemisen näkökulmasta kätilöiden tapaus oli poikkeus, sillä tutkituissa medioissa kilpailukykysopimuksen kohteina olleet kansalaiset jäivät yleensä pimentoon. Esimerkiksi Yleisradion uutis- ja ajankohtaisohjelmissa pääsi ääneen vuosien 2015-2016 kiky-haastatteluissa kaikkiaan yhdeksän niin sanottua tavallista kansalaista, joista vain kolme oli naisia. Journalismissa tällaista 
tavallista henkilöä eli tavista määrittää erityisesti sosiaalisten, kulttuuristen, hallinnollisten tai poliittisten natsojen puute (Seuri 2016, 292), mutta kiky-kamppailun yhteydessä tavikset ovat olleet sidosryhmien edustajia, joilla ei ole merkittävää muodollista asemaa tai valtaa. Äänensä saivat kuuluviin siis eräänlaiset "sidosryhmätavikset" eli yrittäjät tai työntekijät, kuten kätilö Millariikka Rytkönen, joka nousi myöhemmin Tehyn puheenjohtajaksi. Muuten television ja radion uutis- ja ajankohtaisohjelmien haastateltavien jakauma vastaa pitkälti lehtien ja verkkouutisoinnin suurta kuvaa: useimmiten äänessä olivat juuri kiky-kamppailun päätoimijat, mutta toisin kuin Yle.fi-uutisoinnissa ammattijärjestöt pääsivät useammin haastateltavan asemaan kuin hallituksen edustajat.

\section{UUTISVUO VAHVISTAA ENTISESTÄÄN VAHVOJEN ASEMAA}

Kilpailukykysopimuksen uutisvuota rytmittävät tässä artikkelissa tunnistetut juttutihentymät, jotka asettuvat sopimusprosessin kannalta merkityksellisten tapahtumien kohdalle (ks. Kuvio 1). Jaottelimme uutistihentymien jutut sen perusteella, oliko niissä suoria tai epäsuoria lainauksia yhdeltä (monologi), kahdelta (dialogi) vai useammalta (polylogi) toimijalta. Tihentymistä erottuivat selkeästi tietyt päivät, jolloin kutakin juttutyyppiä esiintyi eniten (ks. Taulukko 2). Kiinnostavaa on, kuinka yleisiä juuri monologijutut ovat. Kaksi kolmesta lainauksia sisältävästä jutusta oli monologeja eli juttuja, joissa on siteerattu vain yhtä toimijaa. ${ }^{3}$ Syynä voi olla yhtältä uutiskilpailun maailma, joka tuottaa paineita tapahtumien nopeaan uutisointiin. Lähdekäytäntöä määrittävät kaupalliset paineet ja "vähäisimmän vaivan laki" (Kiviranta 1990). Tiedotusvälineet uutisoivat ensikäden tiedot ja ensimmäiset reaktiot irrallisina paloina, joita sen jälkeen kootaan soveltuvin osin yhteen tai syvennetään.

Toisaalta monologijuttujen korostuminen voi kertoa osaltaan hybridille mediaympäristölle ominaisesta vanhan ja uuden median logiikkojen sekoittumisesta. Sosiaalisessa mediassa palvelu ja sen algoritmit esittävät päivitykset tai viestit uutisvirtana, jossa monologin kaltaiset puheenvuorot virtaavat käyttäjän selatessa niitä. Käyttäjät ovat myös tiedon välittäjiä, jotka levittävät sisältöä ketjukirjeen tapaan verkostoissaan (ks. Klinger ja Svensson 2015). Uutismediassa eri toimijoiden puheenvuorot tuottavat hieman samankaltaista virtausta, jossa korostuvat monologipuheenvuorot. Kiky-kamppailun toimijoiden välinen vuorovaikutus tapahtuu merkittäviltä osin uutisvuon virtauksessa, kun yleisö saa nähtäväkseen ääneen päässeiden toimijoiden näkemyksiä tai kannanottoja peräkkäisissä tai rinnakkaisissa jutuissa, joita julkaistaan uutisoinnin eri vaiheissa. Monelta kantilta asiaa punnitsevien juttujen ja analyysien julkaiseminen on osa perinteisen median toimintaa, mutta tämän tutkimuksen kilpailukykysopimusta käsittelevässä aineistossa niitä oli huomattavasti vähemmän kuin yhdelle toimijalle äänen antavia juttuja.

Merkittävä osa aineiston suorista ja epäsuorista lainauksista on uutisjutuissa. Lainaukset analyyseissä $(1,4 \%)$ ja mielipiteellisissä jutuissa $(2,2 \%)$ muodostavat hyvin pienen osan kokonaisuudesta. Niillä on kuitenkin osansa uutisvuon muodostumisessa eli siinä, miten uutisointi elää prosessin aikana. Hallitus pääsee näissä mielipiteellisissä tai selittävissä jutuissa hieman muita enemmän ääneen, kuten myös ryhmä "muut", joka koostuu pääosin erilaisista asiantuntijoista. Tämä sopii käsitykseen journalismista, jossa ensin uutisoidaan, sitten selitetään, syvennytään ja 
tarjotaan kontekstia. Yksittäinen toimittaja ei useinkaan pääse pintaa syvemmälle ensimmäisessä julkaistussa jutussa. Se kuitenkin rakentaa pohjaa seuraaville uutisille, joissa lähteet tuovat esiin uusia tietoja tai näkemyksiä tai oikovat ensimmäisen uutisen väärinkäsityksiä. Näiden päälle rakentuu kolmas tai useampia kerroksia, jotka kaikki tuottavat lisää yksityiskohtia ja kontekstia. (Ks. Kovach ja Rosenstiel 2014, 58.)

Olemme tutkineet ensisijaisesti siteerattujen lähteiden määrää ja hierarkiaa jutun sisällä, mutta tämän ohella uutisoinnin rytmin näkökulmasta näyttää siltä, että media julkaisee ensin monologijuttuja ja asettaa vasta sen jälkeen eri toimijoita juttujen sisäiseen dialogiin. Tihentymistä ensimmäinen, toinen ja neljäs noudattivat tätä rytmiä. Kolmannen ja viidennen tihentymän kohdalla monologien ja dialogien suurimmat kasaumat osuivat samoille päiville. Kolmannessa tihentymässä 2.12.2015 oli määrällisesti vilkkain kiky-uutispäivä kaikissa kolmessa kategoriassa. Tuon vuorokauden sisällä kaikki monologijutut on julkaistu klo 15.30 mennessä, mikä osaltaan tukee ajatusta, että monologit rytmittävät uutisvuon virtausta. Tämän lisäksi teimme karkean analyysin koko aineiston tasolla, ja sen mukaan STT:n ja Iltalehden uutisoinnissa rytmi monologi-dialogi-polylogi näyttäytyy selkeämpänä kuin Helsingin Sanomissa ja Ylen verkkouutisoinnissa.

Taulukko 2. Monologien, dialogien ja polylogien huippupäivät viidessä valitussa tihentymässä STT:n, Yleisradion, Helsingin Sanomien ja Iltalehden kiky-jutuissa 2015-2016

\begin{tabular}{|l|l|l|l|}
\hline & Monologi & Dialogi & Polylogi \\
\hline 1. tihentymä & 6.5 .2015 & 7.5 .2015 & 6.5 .2015 \\
\hline 2. tihentymä & 8.9 .2015 & 10.9 .2015 & 8.9 .2015 \\
\hline 3. tihentymä & 2.12 .2015 & 2.12 .2015 & 2.12 .2015 \\
\hline 4. tihentymä & 29.2 .2016 & 7.3 .2016 & 8.3 .2016 \\
\hline 5. tihentymä & 3.6 .2016 & 3.6 .2016 & 31.5 .2016 \\
\hline
\end{tabular}

Dialogi- ja polylogijuttujen laadullinen analyysi osoittaa, että usean lähteen siteeraaminen ei kuitenkaan välttämättä tarkoita varsinaista lähteiden välistä vuorovaikutusta jutun sisällä. Esimerkiksi monet usean lähteen jutut ovat itse asiassa koontijuttuja, joissa on vain lueteltu peräkkäin eri toimijoiden reaktioita ajankohtaiseen poliittiseen tapahtumaan kuten hallituksen pakkolakiulostuloon (ks. HS 8.9.2015a; Yle 8.9.2015), reaktioita reaktioihin (STT 8.9.2015) tai kannanottoja kiky-sopimuksen lopulliseen solmimiseen (ks. STT 31.5.2016; HS 4.6.2016). Tällaiset jutut eivät useinkaan sisällä monien eri näkökantojen pohdintaa, vaan kyse on lausuntojen kirjaamisesta eli eräänlaisesta monologien virran taltuttamisesta yhden jutun uomaan. Koontimuoto selittää myös osaltaan sitä, että useamman siteeratun lähteen juttujen kasaumat osuvat kolmessa tihentymässä samalla päivälle kuin monologien: niihin on kerätty päivän mittaan ensin monologina esitettyjä tai tiedotteista poimittuja lainauksia. 
Dialogi osoittautuukin tarkemmassa analyysissä kiinnostavaksi kategoriaksi, sillä dialogi tarkoittaa kahden ihmisen vuoropuhelua tai etymologiansa mukaisesti (dia ja logos) ajatusten virtaamista kahden mielen läpi. Aineistosta koneellisesti tavoitetut dialogit sisältävät kuitenkin harvoin suorien tai epäsuorien lainausten välistä vuorovaikutusta eli liikettä lainausten tai ääneen pääsevien henkilöiden välillä. Kyse on pikemminkin kahden eri toimijan haastattelulausuntojen, tiedotteessa tai tiedotustilaisuudessa ilmaistujen kantojen tai muualta poimittujen puheenvuorojen asettamista peräkkäin. Dialogijutuissa on siis havaittavissa samaa monologien välistä vuorovaikutusta kuin sosiaalisen median uutisvirrassa. Vaikka journalistiseen uutismediaan liitetään idealistinen näkemys areenan tarjoamisesta demokraattiselle vuoropuhelulle, uutismedian arjessa dialogi on usein näennäisdialogia, jossa esitetään ensin yhden toimijan puheenvuoro ja sitten toisen. Uutismedia ei kuitenkaan ole vain "näyttämömestari" (ks. Pietilä 1991, 15), vaan välittäjä ja aktiivinen esittäjä, joka asettaa puheteot osaksi virtaa - joko peräkkäisinä monologeina tai toisiaan seuraavina sidostettuina puheenvuoroina dialogeissa ja polylogeissa.

Hallitustoimijoiden ensisijaisuus ja monologijuttujen korostuminen ovat selkeimmät aineistosta esiin nousevat havainnot. Kaikkein tyypillisimmillään media siteeraa pääministeriä jutun ainoana lähteenä. Juha Sipilä on eniten äänessä sekä monologeissa, dialogeissa että polylogeissa. Monologeiksi määritellyissä jutuissa Sipilää siteerataan 233 kertaa, kun seuraavat eli Lauri Lyly (88), Antti Rinne (49) ja Alexander Stubb (46) tulevat selvästi perässä. Uutisoinnin rytmi ja rakenne (ml. muoto ja ääneen pääsemisen järjestys) eli käytännössä uutisvuon virtaus vahvistaa vahvojen ääntä. Tutkituissa tihentymissä ensinnä ääneen päässeet pystyvät kehystämään ja oikeuttamaan tulevia päätöksiä ja tapahtumia omalta kannaltaan edullisesti. Etenkin pääministerin asema eniten äänessä olevana ja usein ensisijaisena toimijana on tärkeä, sillä ääneen pääseminen on määrittelyn ja kehystämisen valtaa. Eri toimijat korostavat eri puolia, jolloin mahdollisuus muotoilla näkökulmia itse antaa poliittisen etulyöntiaseman. (van Aelst ja Walgrave 2016, 501.) Ensisijaisuuden rooli mahdollisesti vain korostuu, kun hybridissä mediajärjestelmässä nopeudesta on tullut keskeinen mediakamppailun ominaisuus.

Hallitus ja sen pääministeri ovat selvästi eniten äänessä, mutta useamman lainatun toimijan huomioiminen lisää työmarkkinajärjestöjen painoarvoa uutisoinnissa. Ay-liikkeen ja työnantajajärjestöjen dialogiparit ovat hieman yleisempiä kuin jutut, joissa päätoimijoiksi nimetyt ayliikkeen ja hallituksen edustajat ovat äänessä. Samoin yleisin dialogipari henkilötoimijoista on SAK:n Lauri Lyly ja EK:n Jyri Häkämies. Työntekijät pääsevät ääneen sekä hallituksen, työnantajien että toistensa kanssa, kun taas työnantajat pääsevät ääneen sekä dialogissa työntekijöiden kanssa että jutuissa, joissa on huomioitu useita eri toimijoita. Monologien, dialogien ja polylogien analyysi korostaa työnantajien ja opposition roolia sivutoimijoina, jotka pääsevät ääneen päätoimijoiden jälkeen tai rinnalla eli harvemmin itsenäisessä asemassa kamppailua kehystäen. On hyvä huomioida, että kiky-asetelmassa on voinut olla työnantajapuolelle edullistakin, että sitä ei ole vedetty yhtä intensiivisesti kamppailuun mukaan.

Tämän artikkelin nimetyistä toimijoista ryhmä "muut" on uutisoinnin rytmin perusteella hyvin omanlaisensa. Tähän ryhmään kuuluvat asiantuntijat ovat suhteellisesti lähes yhtä usein monologiasemassa kuin hallituksen edustajat, vaikka määrällisesti pääsevätkin ääneen harvemmin kuin päätoimijat. Samoin he esiintyvät dialogissa useimmin juuri hallituksen kanssa. Asiantuntijoista ovat korostetusti äänessä ekonomistit ja muut talouden asiantuntijat pankeista ja tutkimuslaitoksista, mikä alleviivaa kiky-kamppailun "ekonomistista" (ks. Teivainen 2016) 
tulkintaa eli sitä, kuinka asiantuntijahaastattelut kehystävät kamppailua ennen kaikkea talouskysymyksenä, eivät niinkään poliittisena kamppailuna. Esimerkiksi siirtymä historiallisesta yhteiskuntasopimus-käsitteestä kilpailukykysopimukseen tapahtuu pitkälti problematisoimatta. Aineisto tukee myös Aapo Parviaisen (2014) havaintoa, että mediassa paras ekonomisti on pankkiekonomisti eikä esimerkiksi yliopistoprofessori. ${ }^{4}$ Asiantuntijoiden taustalla on merkitystä, sillä uutisjournalismissa painopiste on siirtynyt yhä enemmän faktojen raportoinnista uutistapahtumien tulkintaan (Pitkänen ja Niemi 2016) ja asiantuntijat kommentoivat ajankohtaisia teemoja ja tarjoavat valistuneita arvioita (Albæk 2011; Peters 2013).

\section{PERINTEINEN MEDIA HYÖDYNTÄÄ TIEDOTTEITA JA SOMEPÄIVITYKSIÄ INFORMAATIOTUKIAISINA}

Poliitikot ja työmarkkinatoimijat pyrkivät pääsemään ääneen uutismediassa etenkin tiedotteilla, mutta myös sosiaalisen median päivityksillä. Somepäivityksissä toimijat muotoilevat viestinsä suoraan yleisölle, ja verkottuneessa ympäristössä päivityksiä seuraavat ja niistä uutisoivat journalistiset mediat ovat osa tuota yleisöä. Hybridissä mediajärjestelmässä informaatio siis virtaa sekä sosiaalisesta mediasta journalismiin että toisin päin. Reunanen ja Väliverronen (2020, 175) kirjoittavat, että "mediajulkisuudesta on tullut talous- ja työmarkkinapolitiikalle entistä tärkeämpi ja tiedostetumpi areena", mikä on tarkoittanut politiikan instituutioissa "viestinnän näkökulman korostumista, julkisuuden seurannan tehostumista ja lisääntynyttä herkkyyttä reagoida julkisuuden agendalle nousseisiin kysymyksiin”. Työmarkkinatoimijat hyödyntävät julkisuutta luodakseen painetta muille neuvotteluosapuolille ja saavuttaakseen valtaresursseja pienemmässä piirissä käytäviä neuvotteluja ajatellen (Kunelius ym. 2010, 437).

Tämän kiky-tapaustutkimuksen perusteella tiedotteet ja sosiaalisen median päivitykset ovat journalistisen äänen antamisen eli median tekemien valintojen näkökulmasta toissijaisia suhteessa haastatteluihin ja tiedotustilaisuuksissa tapahtuvaan viestintään. Tiedotteet ja somepäivitykset voivat olla yksittäisille toimijoille tai yksittäisissä tapauksissa merkityksellisiä, mutta määrällisesti ja tapahtumien kehystämisen kannalta ne jäävät toimituksen tuottaman materiaalin jalkoihin. Toimituksen itse tekemät haastattelut tai uutistilanteessa saadut kommentit ovat uutisoinnissa ensisijaisia, jolloin tiedotteista ja somesta tehdyt nostot ovat enemmän täydentävää materiaalia - siis sellaista, jota Oscar Gandy (1982) on kutsunut informaatiotukiaisiksi. Tätä toissijaisuutta voi kuvata kolmen eri huomion avulla.

Ensimmäinen huomio liittyy tiedotemateriaalin kiertoon. Ylivoimaisesti eniten lainattu tiedote on Valtioneuvoston tiedotteessa kokonaisuudessaan tekstinä julkaistu pääministeri Sipilän tv-puhe (Yle A-studio 16.9.2015). Kyse ei ole perinteisessä mielessä tiedotemateriaalin kierrosta, vaan julkisen puheteon uutisoimisesta. Valtioneuvosto on julkaissut puheen kokonaisuudessaan tiedotteena saavutettavuuden vuoksi ja palvellakseen yleisöä. Tiedotemateriaalin ja somepäivitysten kierto onkin ainakin osittain sidoksissa uutistapahtumiin. Pääministerin kohdalla ne täydentävät uutisointia lähinnä silloin, kun pääministeriä ei ole tavoitettu kommentoimaan. Näin esimerkiksi tapauksessa, jossa Sipilä tarkensi Twitter-viestissään, että aiemmin mainittu sairauspäiväkarenssi ei koske sairaan lapsen kanssa kotiin jääviä vanhempia 
(HS 8.9.2015b). Pääministeriä ei selvästikään tavoitettu haastateltavaksi, sillä jutussa on äänessä yleensä taustalla pysytellyt pääministerin poliittinen erityisavustaja Riina Nevamäki.

Toinen huomio koskee tiedotteiden läpäisevyyttä mediassa. Tiedotelainauksissa työnantajat saavat suhteellisesti enemmän tilaa kuin muussa uutisoinnissa. Viidestä eri huipusta ${ }^{5}$ kolmessa Suomen yrittäjät (SY) on tiedotteista lainatuin toimija. Tämän ohella Kuntatyönantajat (KT) on kolmannen huipun lainatuin ja EK neljännen huipun toiseksi lainatuin. Perinteisen kolmikantaisen neuvotteluprosessin ulkopuolelle jäävä SY pääsi tiedotteillaan kaikissa medioissa hyvin esille, mutta Helsingin Sanomissa se on eniten tiedotteista siteerattu työmarkkinajärjestö. Sen sijaan, että havainto korostaisi juuri SY:n merkitystä työmarkkinakentällä, se pikemminkin tukee ajatusta tiedotteiden toissijaisuudesta suhteessa muuhun materiaaliin. Hallituksen sekä SAK:n, STTK:n ja EK:n edustajat pääsevät ääneen haastatteluissa ja tiedotustilaisuuksissa, jolloin toimittajat täydentävät uutisointiaan muiden ei-niin-keskeisten sidosryhmien kuten juuri SY:n tai KT:n tiedotemateriaalilla.

Työnantajajärjestöjen tiedotteiden kierto ei palaudu myöskään tiedotteissa käytettyyn kieleen, vaan kyse on todennäköisemmin juuri toimituksellisista valinnoista ja merkitysten virran hallitsemisesta. Laadullisen analyysin perusteella tiedotteissa käytetty kieli vaihteli toimijoiden sekä tapahtumien mukaan. Värikästä ja metaforia sisältävää kieltä on varsinkin SAK:n, Akavan ja STTK:n teksteissä, ja media siteerasi tiettyjä värikkäitä ilmauksia muita useammin: esimerkiksi STTK:n tiedotteen (8.9.2015) ilmausta "hallitus leikkii tulitikuilla ruutitynnyrin lähellä" ja SY:n tiedotteesta (29.2.2016) poimittua "(j)os tämä neuvottelutulos toteutetaan, korporatismi voittaa ja demokratia ja työllisyys häviävät". Kiky-juttujen ja siteerattujen tiedotteiden metaforia tutkinut Eliisa Vainikka kollegoineen (2020) toteaa, että voimakkaat metaforat ovat yksi keino saada ääni kuuluville mediassa, mutta niillä on merkitystä myös sen kannalta miten keskustelu kilpailukykysopimuksesta sanallistettiin ja millaisissa metaforamaailmoissa sitä koskevaa ymmärrystä rakennettiin.

Kolmas huomio koskee poliittisen viestinnän rajojen häilymistä, kun blogit ja sosiaalinen media ovat tulleet tiedotevetoisen viestinnän rinnalle. Tarkasteltaessa mediassa siteerattuja somepäivityksiä päätoimijat eli hallituksen ja ay-liikkeen edustajat pääsivät muita enemmän ääneen, mutta suhteessa muuhun uutisointiin oppositiota lainattiin enemmän. Suoria tai epäsuoria somelainauksia on kuitenkin aineistossa alle 200, joten määrällisesti pitkälle meneviä johtopäätöksiä ei kannata tehdä. Selvää kuitenkin on, että hybridissä mediajärjestelmässä tiedotteiden ja somepäivitysten rajat häilyvät. Esimerkiksi SDP:n puheenjohtajan Antti Rinteen kikyä koskevat, mediassa esiin nostetut Facebook-päivitykset alleviivaavat, että napakat twiitit tai perinteiset tiedotteet eivät ole ainoita tapoja levittää poliittista viestiä. Median lainaamat (STT 2.3.2016; IL 4.6.2016; Yle 14.7.2016) Rinteen Facebook-statuspäivitykset (Rinne 2.3.2016; 3.6.2016; 14.7.2016) ovat pituudeltaan 500-2 000 merkin pituisia. Poliitikon omalle edustajasivulle kirjoitetut päivitykset toimivat henkilökohtaisina tiedotteina, joissa muoto ja pituus eivät sido kirjoittajaa. Helppolukuiset somepäivitykset ja blogikirjoitukset sopivat hyvin hybridiin mediaympäristöön, sillä ne ovat olemuksellisesti osa julkaisujen virtaa, josta toimittajat voivat poimia valmista sitaattimateriaalia juttuihinsa.

Tämän tutkimuksen perusteella toimittajat menevät ja pääsevät lähteille suoraan ja täydentävät uutisointia tiedote- ja somemateriaalilla tilanteen mukaan. Internet on muokannut journalismin ja lähteiden välistä tasapainoa, mutta ainakaan työmarkkinakontekstissa pelot yksipuolisen 
viestinnän läpäisevyydestä ja uutisointiin liittyvän neuvottelun ohittamisesta (ks. Broersma ja Graham 2013, 461-462) eivät näytä toteutuneen. Toimittajat saattavat yksittäisissä tapauksissa käyttää somepäivitystä primäärilähteenä tai jopa jutun ainoana siteerattuna lähteenä (ks. STT 19.2.2016; STT 4.3.2016), mutta kiky-uutisoinnissa haastattelu tai tiedotustilaisuuden kaltainen tilannekuvaus on edelleen ensisijaista. Lisäksi analyysimme perusteella tunnistettujen toimijoiden sosiaalisen median tilit ovat hybridissä mediajärjestelmässä lähteitä siinä missä perinteisemmät tiedotteet. Niitä voi tulkita pyrkimyksenä paitsi puhutella omaa yleisöä myös päästä ääneen journalistisessa mediassa: poliittiset somepäivitykset ovat agendan rakentamisen välineitä (Parmelee 2014). Onhan perinteisen median ja sosiaalisen median näkyvyys hyvin vastavuoroista (ks. Kruikemeier ym. 2018, 232). Kun puhutaan perinteisen median julkaisulogiikasta ja sosiaalisen median toimintalogiikasta, huomion kiinnittäminen median seulan läpäiseviin somepäivityksiin voisi olla perusteltu tutkimusaihe, joka osaltaan valottaisi näiden logiikoiden yhteenkietoutumista ja uutisvuon virtausta tästä artikkelista poikkeavalla tavalla.

\section{LOPUKSI}

Lähteet ovat olennainen osa journalismia. Jopa niin olennainen, että Marcel Broersma kollegoineen $(2013,388)$ kirjoittaa, että uutiset syntyvät toimittajien ja lähteiden "kosiskelunäytöksestä". Toimittajien on kyettävä viettelemään lähteet osallistumaan uutisten tekemiseen antamalla tietoa ja tarjoamalla kiinnostavia, vetovoimaisia lausuntoja. Toimittajan ja lähteiden välinen dynamiikka on journalistisen esittämisen ytimessä. Toimittajat tekevät jatkuvasti rajanvetoa siitä, mikä kuuluu julkisuuteen ja mikä ei, kun taas lähteet pyrkivät esille viestimällä eri tavoin toimittajille siitä, mistä toimittajien tulisi kiinnostua. Internet on horjuttanut tätä asetelmaa. Sosiaalisen median maailmassa eri toimijat pyrkivät vaikuttamaan uutisvuon virtauksiin ja saamaan sanottavansa mahdollisimman laajalle puhuttelemalla suoraan yleisöä ja tuottamalla medialle sopivaa materiaalia. Chadwickin $(2017,213)$ käsitteistöä soveltaen julkisuuden portinvartijoiden maailmasta on siirrytty hybridiin mediajärjestelmään, jossa on kyse jatkuvasta rajojen piirtämisen, hämärtämisen ja ylittämisen prosessista, jossa vanhan ja uudemman median logiikat kohtaavat, kilpailevat ja muuttuvat.

Tässä artikkelissa on empiirisesti kuvattu, miten juuri perinteinen media kykenee liikuttamaan vallan virtoja antaessaan äänen eri toimijoille. Tuloksien tulkinnassa on olennaista huomioida uutisoinnin konteksti eli työmarkkinakamppailu, jossa on tunnistettavat institutionaaliset toimijat. Onkin kiinnostavaa, miten selkeästi artikkeli vahvistaa aiemmissa tutkimuksissa havaitun eliittilähteiden ylivallan (ks. Brown ym. 1987; Sigal 1973) ja "supervaikuttajien" vahvuuden (ks. Vesa ym. 2018; Vesa ja Kantola 2016). Ääneen pääsevät etenkin kiky-kamppailun päätoimijat eli hallituksen ja ammattiyhdistysliikkeen edustajat. Pääministeri Juha Sipilä on selkeästi siteeratuin lähde, mikä kertoo pitkittyneen uutistapahtuman henkilöitymisestä juuri häneen. Artikkelin havainnot vahvistavat uutistutkimuksen tuloksia legitimoitujen rutiinilähteiden käytöstä (Tuchman 1978) ja helposti saavutettavien lähteiden hyödyntämisestä (Gans 1979). Perinteinen journalistinen media ja sen asema tai legitimaatio ovat edelleen sidoksissa median kiinnittymiseen muihin instituutioihin. 
Hybridin mediajärjestelmän perusajatukseen kuuluu, että uusien ja vanhojen medioiden logiikat sekoittuvat. Vain hieman kärjistäen perinteisen median asema on levännyt hierarkian varassa, kun taas sosiaalisen median alustat tunnustavat verkostojen logiikkaa. Kiky-prosessin uutisoinnissa näkyy kyllä, miten fyysiset paikat ja tapahtumat, internet ja perinteinen media muodostavat verkoston, jossa merkitysten anto tapahtuu. Silti papacharissilaisen kollektiivisen kerronnan (Papacharissi 2015) sijaan hierarkiat korostuvat uutisvuon virtauksissa. Kikyuutisointi on lopulta hyvin perinteistä. Se on kiinni työmarkkina-asetelmassa ja vakiintuneissa positioissa. Toimittajat antavat äänen niille, jotka ovat keskeisiä toimijoita neuvotteluissa sen sijaan, että ääneen pääsisivät ne, joita päätökset ensisijaisesti koskevat. Tutkittujen lainausten perusteella kiky-kamppailun institutionaaliset toimijat hyötyvät haastatteluiden ohella perinteisistä asetelmallisista medialle suunnatuista tilanteista kuten tiedotustilaisuuksista tai vaikka pääministerin virka-asunnon luona tehdyistä haastatteluista. Sen sijaan tiedotteet ja somepäivitykset toimivat toissijaisina lähteinä, jotka vaikuttavat vallan virtauksiin haastatteluita ja tiedotustilaisuuksia vähemmän. Somemateriaalin käyttö vahvistaa perusasetelmaa sen sijaan, että loisi perusuutisoinnin painotuksista irrallisen ääneen pääsemisen tason.

Tutkimuksemme tulokset ohjaavat huomiota myös perinteisen median kykyyn toimia julkisen keskustelun areenana, puhetekojen kuraattorina ja eri toimijoiden välisen dialogin mahdollistajana. Tutkimuksen aineistossa kaksi kolmesta suoria tai epäsuoria lainauksia sisältävistä jutuista oli määriteltävissä monologiksi, joten mediadialogi on ainakin kiky-kamppailun kontekstissa useimmiten monologien välistä. Tällainen dialogisuus muistuttaa sosiaalisen median julkaisulogiikkaa, jossa puheenvuorot asettuvat peräkkäin tai rinnakkain käyttäjän uutisvirrassa. Tätä monologisuutta korostaa entisestään, että tyypitellyissä dialogeissa ja polylogeissa on tunnistettavissa samaa monologien välistä vuorovaikutusta, eräänlaista näennäisdialogia. Osa journalismin legitimaatiosta demokratian kannalta keskeisenä instituutiona perustuu rooliin, jossa media mahdollistaa yhteiskunnallisten toimijoiden dialogin tavalla, johon muut eivät pysty (ks. Hornmoen ja Steensen 2014). Muutkin julkaisijat tai verkoston keskeiset solmukohdat - jopa yksittäiset kansalaiset - pystyvät kuitenkin keräämään eri toimijoiden puheenvuoroja ja kokoamaan ne yhdeksi kokonaisuudeksi. Sosiaalisen median uutisvirta ja sitä määrittävät algoritmit luovat jatkuvasti puhetekojen dialogisuutta, joka perustuu yksittäisten toimijoiden monologien virtaukseen. Tätä tutkimusta laajempi historiallinen pitkittäistutkimus voisi osoittaa, onko monologijuttujen korostumisessa kyse journalistisen dialogin ominaisuudesta vai massamedialogiikan ja verkottuneen medialogiikan limittymisestä tai kietoutumisesta yhteen. Joka tapauksessa perinteinen media näyttäisi nojaavan vahvemmin pääsyyn eliittilähteille kuin siihen, että se pystyisi tuottamaan muodoltaan erityistä tai erityisen vivahteikasta vuorovaikutusta noiden lähteiden välillä.

Internetin ja sosiaalisen median nousu ovat johtaneet journalismin, poliittisten toimijoiden ja yleisön välisten valtasuhteiden muutoksiin, ja yhä useammat toimijat pyrkivät hyödyntämään offline ympäristössä saavuttamansa institutionaaliset vahvuutensa myös sosiaalisen median verkostoissa (ks. Broersma ja Graham 2016). Tässä artikkelissa käsitellyssä STT:n, Ylen, HS:n ja IL:n työmarkkinauutisoinnissa ääneen pääseminen korostaa institutionaalisten työmarkkinatoimijoiden ja perinteisen median yhteenkytkentää. Kiky-kamppailulla oli suomalaisessa mediassa pääministerin kasvot. Lisäksi päätoimijat hallitus ja ay-liike saivat paljon tilaa siinä missä etenkin kansalaisten ääni jäi lähes kuulumattomiin. Kiky-kamppailun kaltaisessa tilanteessa - jossa institutionaaliset toimijat ovat vahvoja - perinteinen media kykenee toimimaan 
uutisvuon hallitsijana, jolla on edelleen valtaa rytmittää merkitysten virtaa. Tulevaisuudessa onkin kiinnostavaa nähdä, toimiiko median access eli pääsy lähteille ja eliittilähteisiin sitoutuminen edelleen voimavarana. Sosiaalinen media pystyy kyllä tarjoamaan perinteistä mediaa inklusiivisemman toimintakentän, mutta se ei toistaiseksi ole pystynyt rakentamaan samanlaista institutionaalisten toimijoiden kohtaamisen areenaa. Yksi keskeinen kysymys voi olla, kuka pystyy tarjoamaan funktionaalista ja nykyistä vivahteikkaampaa dialogia julkisella näyttämöllä.

\section{TUTKIMUKSEN RAHOITUS}

Tämä tutkimus on osa Suomen akatemian (320286) rahoittamaa Media ja yhteiskunta -ohjelman hanketta "Vallan virrat - media politiikan alustana ja tekijänä”.

\section{KIITOKSET}

Kiitämme lehdistötiedoteaineistosta Paula Koskinen Sandbergia, joka ystävällisesti jakoi aineistoaan käyttöömme tutkijatohtorihankkeestaan "Neoliberalizing Welfare State Employment: Ideology, Institutional Agency, and Gendered Labour Market Outcomes".

\section{VIITTEET}

1. Analyysin toteutuksessa hyödynnettiin Turku Neural Parser -kirjaston (Kanerva ym. 2018) tuottamaa sanojen perusmuotoistusta, sekä sanaluokka ja riippuvuusjäsennystä.

2. Tekstin uudelleenkäyttö tunnistettiin eri lähteistä lauseparien avulla siten, että parin toinen lause oli peräisin lehdistötiedotteesta ja toinen aineistomme muista mediateksteistä. Lauseet oli julkaistu viikon sisällä toisistaan, ne olivat yli kuusi sanaa pitkiä ja niiden sisältämien sanojen perusmuotovektorien välinen kosinisamankaltaisuus oli enemmän kuin 0.6. Tuloksista poistettiin hukkasanalistan avulla kymmenen eniten aineistossa käytettyä sanaa ja merkkiä. Lähempään tarkasteluun otettiin viiden keskustelutihentymän aikana esiintyneet lauseparit.

3. Tässä artikkelissa koneellisesti kategorisoidut monologit voivat sisältää erilaisia ääneen pääsemisen tapoja. Tyypittelyn perusteella monologin arkkityyppi on yhden henkilön haastattelu. Tämän ohella monologi voi olla juttu, jossa ääneen pääsevän henkilön sitaatit on poimittu tiedotteesta tai muista lähteistä kuten toisen median jutuista tai juttu, jossa henkilöä lainataan ainoastaan epäsuorasti. Lisäksi aineistossa on monologiksi laskettavia juttuja, joissa äänessä on haastateltu henkilö sekä hänen taustaorganisaationsa esimerkiksi ammattiliiton lainatun kannanoton muodossa. Lisäksi päätoimijat huomioineessa analyysissa on huomioitu monologeina jutut, joissa on yhden toimijaryhmän näkemys suorana tai epäsuorana lainauksena sekä jutut, joissa on voinut olla kaksi saman päätoimijaryhmän edustajaa äänessä. 
4. Kaikilla tutkituilla medioilla on ollut omat "suosikkiekonomistinsa" kuten Ylen ja Iltalehden suosima Nordean pääekonomisti Aki Kangasharju tai STT:n suosima OP:n pääekonomisti Reijo Heiskanen. Helsingin Sanomat sen sijaan antoi muita selvästi useammin äänen Nordean ekonomisteille Olli Kärkkäiselle ja Jan von Gerichille.

5. Tässä analyysissä aineistosta on poistettu VN:n 16.9.2015 tiedote pääministeri Juha Sipilän tv-puheesta.

\section{LÄHTEET}

van Aelst, Peter ja Walgrave, Stefaan. 2011. Minimal or Massive? The Political Agenda-Setting Power of the Mass Media According to Different Methods. The International Journal of Press/Politics 16:3, 295-313.

van Aelst, Peter ja Walgrave, Stefaan. 2016. Information and Arena: The Dual Function of the News Media for Political Elites. Journal of Communication, 66:3, 496-518.

https://doi.org/10.1111/jcom.12229

Albæk, Erik. 2011. The Interaction between Experts and Journalists in News Journalism. Journalism 12:3, 335-348. https://doi.org/10.1177/1464884910392851

Bachrach, Peter ja Baratz, Morton S. 1962. Two Faces of Power. The American Political Science Review 56:4, 947-952.

Bennett, W. Lance ja Pfetsch, Barbara. 2018. Rethinking Political Communication in a Time of Disrupted Public Spheres. Journal of Communication 68: 243-253. https://doi.org/10.1093/joc/jqx017

Bennett, W. Lance ja Iyengar, Shanto. 2008. A New Era of Minimal Effects? The Changing Foundations of Political Communication. Journal of Communication 58:4, 707-731.

https://doi.org/10.1111/j.1460-2466.2008.00410.x

Boydstun, Amber E. 2013. Making the News: Politics, the Media, and Agenda Setting. Chicago: University of Chicago Press.

Broersma, Marcel ja Graham, Todd. 2016. Tipping the Balance of Power. Social Media and the Transformation of Political Journalism. Teoksessa Axel Bruns, Eli Skogerbø, Christian Christensen, Anders Olaf Larsson ja Gunn Enli (toim.), The Routledge Companion to Social Media and Politics. New York ja Milton Park: Routledge, 89-103.

Broersma, Marcel, den Herder, Bas ja Schohaus, Birte. 2013. A Question of Power. Journalism Practice 7:4, 388-395. https://doi.org/10.1080/17512786.2013.802474

Broersma, Marcel ja Graham, Todd. 2013. Twitter as a news source: How Dutch and British newspapers used tweets in their news coverage, 2007-2011. Journalism Practice 7:4, 446-464. https://doi.org/10.1080/17512786.2013.802481

Brown, Jane Delano, Bybee, Carl R., Wearden, Stanley T. ja Straughn, Dulcie Murdoch. 1987. Invisible Power: Newspaper News Sources and the Limits of Diversity. Journalism Quarterly 64:1, 45-54. https://doi.org/10.1177\%2F107769908706400106

Castells, Manuel. 2009. Communication Power. Oxford: Oxford University Press.

Chadwick, Andrew. 2017. The Hybrid Media System: Politics and Power. Second Edition. New York: Oxford University Press. 
Chong, Dennis ja Druckman, James N. 2013. Counterframing effects. The Journal of Politics 75:1, 1-16. https://doi.org/10.1017/S0022381612000837

Couldry, Nick. 2006. Listening Beyond the Echoes: Media, Ethics, and Agency in an Uncertain World. Lontoo: Routledge.

Couldry, Nick. 2008. Media and the problem of voice. Teoksessa Nico Carpentier ja Benjamin De Cleen (toim.), Participation and media production: Critical reflections on content creation. Cambridge: Cambridge Scholars Press, 15-26.

Dahl, Robert. 1957. The Concept of Power. Behavioral Science 2:3, 201-215.

Dayan, Daniel ja Katz, Elihu. 1992. Media events: The live broadcasting of history. Cambridge: Harvard University Press.

Djerf-Pierre, Monika ja Shehata, Adam. 2017. Still an agenda setter: Traditional news media and public opinion during the transition from low to high choice media environments. Journal of Communication 67:5, 733-757. https://doi.org/10.1111/jcom.12327

Eide, Martin. 2007. Encircling the Power of Journalism. Nordicom Review, Jubilee Issue 2007, 21-29.

Elomäki, Anna, Kantola, Johanna, Koivunen, Anu ja Ylöstalo, Hanna. 2016. Kamppailu tasa-arvosta. Tunne, asiantuntijuus ja vastarinta strategisessa valtiossa. Sosiologia 53:4, 257-275.

Entman, Robert. 2007. Framing Bias Media in the Distribution of Power. Journal of Communication 57, 163-173.

Fairclough, Norman. 1992. Discourse and Social Change. Cambridge: Polity.

Gandy, Oscar. 1982. Beyond agenda setting: information subsidies and public policy. Norwood: Ablex Publishing Company.

Gans, Herbert J. 1979. Deciding What's News. A Study of CBS Evening News, NBC Nightly News, Newsweek and Times. New York: Vintage Books.

Goel, Sharad, Anderson, Ashton, Hofman, Jake ja Watts, Duncan J. 2016. The Structural Virality of Online Diffusion. Management Science 62:1, 180-196. https://doi.org/10.1287/mnsc.2015.2158

González-Bailón, Sandra. 2017. Decoding the Social World: Data Science and the Unintended Consequences of Communication. Lontoo: MIT Press.

Hachten, William A. 2005. The Troubles of Journalism: A Critical Look at What's Right and Wrong with the Press. Kolmas painos. Mahwah: Lawrence Erlbaum Associates.

Hepp, Andreas ja Couldry, Nick. 2010. Introduction: media events in globalized media cultures. Teoksessa Nick Couldry, Andreas Hepp ja Friedrich Krotz (toim.), Media Events in a Global Age. Abingdon: Routledge, 1-20.

Hornmoen, Harald ja Steensen, Steen. 2014. Dialogue as a Journalistic Ideal. Journalism Studies 15:5, 543-554. https://doi.org/10.1080/1461670X.2014.894358

Jenkins, Henry, Ford, Sam ja Green, Joshua. 2013. Spreadable Media: Creating Value and Meaning in a Networked Culture. New York: New York University Press.

Kanerva, Jenna, Ginter, Filip, Miekka, Niko, Leino, Akseli ja Salakoski, Tapio. 2018. Turku Neural Parser Pipeline: An End-to-End System. Teoksessa CoNLL 2018 Shared Task. Proceedings of the CoNLL 2018 Shared Task: Multilingual Parsing from Raw Text to Universal Dependencies. Brussels: Association for Computational Linguistics, 133-142. https://doi.org/10.18653/v1/K18-2013

King, Gary, Schneer, Benjamin ja White, Ariel. 2017. How the news media activate public expression and influence national agendas. Science 358, 776-780. https://doi.org/10.1126/science.aao1100

Kiviranta, Uolevi. 1990. Vähäisimmän vaivan laki journalismissa. Tiedotustutkimus 13:3, 49-55. 
Klinger, Ulrike ja Svensson, Jakob. 2015. The emergence of network media logic in political communication: A theoretical approach. New Media \& Society 17:8, 1241-1257. https://doi.org/10.1177\%2F1461444814522952

Kovach, Bill ja Rosenstiel, Tom. 2014. The Elements of Journalism: What Newspeople Should Know and the Public Should Expect. Kolmas painos. New York: Crown.

Kruikemeier, Sanne, Gattermann, Katjana ja Vliegenthart, Rens. 2018. Understanding the dynamics of politicians' visibility in traditional and social media. The Information Society 34:4, 215-228. https://doi.org/10.1080/01972243.2018.1463334

Kunelius, Risto, Noppari, Elisa ja Reunanen, Esa. 2010. Media vallan verkoissa. Tiedotusopin laitoksen julkaisuja, Sarja A 112. Tampere: Tampereen yliopisto.

Kylä-Laaso, Miikaeli. 2019. Sivuutettu sukupuoli: sukupuolten tasa-arvon legitimiteetti kilpailukykysopimusta koskevissa eduskuntakeskusteluissa. Yhteiskuntatutkimuksen tutkinto-ohjelman pro gradu -tutkielma. Tampere: Tampereen yliopisto.

Lukes, Steven. 2005. Power: A Radical View. Toinen painos. Basingstoke: Palgrave Macmillan.

Luostarinen, Heikki. 2002. Moneksi muuttuva journalismi. Teoksessa Touko Perko, Raimo Salokangas ja Heikki Luostarinen (toim.), Median varjossa. Jyväskylän yliopisto, Mediainstituutti, 22-29.

McCombs, Maxwell. 2014. Setting the Agenda. The Mass Media and Public Opinion. Toinen painos. Cambridge: Polity.

Papacharissi, Zizi. 2015. Toward New Journalism(s). Journalism Studies 16:1, 27-40. https://doi.org/10.1080/1461670X.2014.890328

Papacharissi, Zizi. 2016. Affective publics and structures of storytelling: sentiment, events and mediality, Information. Communication \& Society 19:3, 307-324.

https://doi.org/10.1080/1369118X.2015.1109697

Parmelee, John H. 2014. The agenda-building function of political tweets. New Media \& Society 16:3, 434-450. https://doi.org/10.1177/1461444813487955

Parviainen, Aapo. 2014. Mediassa paras ekonomisti on pankkiekonomisti. Kansantaloudellinen aikakauskirja 110:4, 574-581.

Peters, Hans Peter. 2013. Scientists as public communicators. Proceedings of the National Academy of Sciences 110:Supplement 3, 14102-14109. https://doi.org/10.1073/pnas.1212745110

Pietilä, Kauko. 2012. Journalismi ammattina. Helsinki: Gaudeamus.

Pietilä, Kauko ja Sondermann, Klaus. 1994. Sanomalehden yhteiskunta. Tampere: Yhteiskuntatieteiden tutkimuslaitos ja Vastapaino.

Pietilä, Veikko. 1991. Sanoista tekoihin. 'Vieraan puheen' vastaanotosta lehtiuutisessa. Tiedotustutkimus 14:4, 5-18. https://doi.org/10.23983/mv.64360

Pitkänen, Ville ja Niemi, Mari K. 2016. Hallitsematon ja houkutteleva media. Yhteiskuntatieteilijöiden näkemyksiä julkisesta asiantuntijuudesta. Yhteiskuntapolitiikka 81:1, 5-16.

Rainio-Niemi, Johanna. 2014. Nordic Paradox of Openness and Consensus: The Case of Finland. Teoksessa Norbert Götz ja Carl Marklund (toim.), The Promise of Openness: Cultures and Paradoxes. Leiden: Brill, 27-49.

Reunanen, Esa. 2017. Kiristystä vai kilpailukykyä? Auktoriteettiperformassit ja strategiset kertomukset neuvotteluissa "yhteiskuntasopimuksesta". Politiikka 59:2, 96-113.

Reunanen, Esa ja Kunelius, Risto. 2020. The Transformation of Communicative Power into Political Power. Communication Theory 30:1, 1-20. 
Reunanen, Esa ja Väliverronen, Jari. 2020. Tupo ja media: Talous- ja työmarkkinapoliittisen julkisuuden toimintahorisontit kolmella vuosikymmenellä. Tampere: Tampere University Press.

Richardson, John. 2006. Who gets to speak? A study of sources in the broadsheet press. Teoksessa Elizabeth Poole ja John Richardson (toim.), Muslims and the News Media. Lontoo: I.B. Tauris, 103-115.

Sampson, Tony. 2012. Virality: Contagion Theory in the Age of Networks. Minneapolis: University of Minnesota Press.

Schudson, Michael. 2003. The Sociology of News. New York ja Lontoo: W. W. Norton \& Company.

Schudson, Michael. 2020. Journalism. Why It Matters. Cambridge: Polity.

Seuri, Olli. 2016. Historian journalistinen esittäminen. 1960-luku Helsingin Sanomissa vuosina 2008 ja 2013. Tampere. Tampere University Press 2016.

Shehata, Adam ja Strömbäck, Jesper. 2013. Not (Yet) a New Era of Minimal Effects: A Study of Agenda Setting at the Aggregate and Individual Levels. The International Journal of Press/Politics 18:2, 234255. https://doi.org/10.1177/1940161212473831

Sigal, Leon. V. 1973. Reporters \& Officials: The Organisation \& Politics of Newsmaking. Lexington: D. C. Heath.

Sjøvaag, Helle ja Pedersen, Truls. 2018. The effect of direct press support on the diversity of news content in Norway. Journal of Media Business Studies 15: 300-316.

Skogerbø, Eli ja Kunelius, Risto. 2017. Introduction - Political communication in networked societies. Northern Lights: Film \& Media Studies Yearbook. https://doi.org/10.1386/nl.15.1.3_2

Skogerbø, Eli ja Krumsvik, Arne H. 2015. Newspapers, Facebook and Twitter. Journalism Practice 9:3, 350-366. https://doi.org/10.1080/17512786.2014.950471

Taskinen, Pertti. 2019. Palkansaajanaisten työaika piteni kilpailukykysopimuksen myötä. Tieto \& trendit 18.11.2019. http://www.stat.fi/tietotrendit/artikkelit/2019/palkansaajanaisten-tyoaika-pitenikilpailukykysopimuksen-myota/. Viitattu 12.10.2020.

Teivainen, Teivo. 2016. Ekonomismi ja demokratian tulevaisuus. Teoksessa Sari Kivistö, Sami Pihlström ja Mikko Tolonen (toim.), Talous ja moraali. Helsinki: Gaudeamus, 107-124.

Tuchman, Gaye. 1978. Making News. A Study in the Construction of Reality. New York: The Free Press.

Vainikka, Eliisa, Kanner, Antti, Era, Riikka, Harju, Auli, Koivunen, Anu, Seuri, Olli ja Mäkelä, Eetu. 2020. Kilpailukykyloikasta ruutitynnyriin. Metaforat ja affektiivisuus poliittisen kriisin journalismissa. Media \& viestintä 43:4, 247-271. https://doi.org/10.23983/mv.100616

Vesa, Juho ja Kantola, Anu. 2016. Kuka pääsee mukaan? Miten järjestöjen ääni kuuluu lakien valmistelussa. Valtioneuvoston kanslia. Valtioneuvoston selvitys- ja tutkimustoiminnan julkaisusarja 59/2016. http://tietokayttoon.fi/julkaisu?pubid=15502. Viitattu 12.10.2020.

Vesa, Juho, Kantola, Anu ja Binderkrantz, Anne. 2018. A Stronghold of Routine Corporatism? The Involvement of Interest Groups in Policy Making in Finland. Scandinavian Political Studies 41:4, 239-262. https://doi.org/10.1111/1467-9477.12128

Vonbun, Ramona, Kleinen-von Königslöw, Katharina ja Schoenbach, Klaus. 2016. Intermedia AgendaSetting in a Multimedia News Environment. Journalism 17: 8, 1054-73. https://doi.org/10.1177/1464884915595475

Walgrave, Stefaan ja van Aelst, Peter. 2006. The Contingency of the Mass Media's Political Agenda Setting Power: Toward a Preliminary Theory. Journal of Communication 56:1, 88-109.

Wihbey, John P. 2019. The Social Fact. News and Knowledge in a Networked World. Lontoo: MIT Press. Zelizer, Barbie. 2018. Seeing the Present, Remembering the Past: Terror's Representation as an Exercise 
in Collective Memory. Television \& New Media 19:2, 136-145.

https://doi.org/10.1177/1527476417695592

Witschge, Tamara, Anderson, CW, Domingo, David ja Hermida, Alfred. 2019. Dealing with the mess

(we made): Unraveling hybridity, normativity, and complexity in journalism studies. Journalism 20:5, 651-659. https://doi.org/10.1177/1464884918760669.

\section{Viitatut medialähteet}

HS 3.8.2015. Nytin toimitus HS. Juha esitteli yhteiskuntasopimustaan Alexanderille, Jyrille, Markulle, Jarille, Juhanille, Laurille, Antille ja Sturelle (taustalla Paula). Helsingin Sanomat. Saatavilla verkossa: https://www.hs.fi/nyt/art-2000002842527.html. Viitattu 14.10.2020.

HS 8.9.2015a. Nieminen, Martta ja Teittinen, Paavo. Näin säästötoimenpiteitä kommentoitiin: "Hallitus romuttaa suomalaista sopimusyhteiskuntaa" - "Hallituksen toimet ovat täysin välttämättömiä". Helsingin Sanomat. Saatavilla verkossa: https://www.hs.fi/politiikka/art-2000002850987.html. Viitattu 14.10.2020.

HS 8.9.2015b. Mykkänen, Pekka. Sipilä: Sairauspäiväkarenssi ei koske sairaan lapsen kanssa kotiin jäävää. Helsingin Sanomat. Saatavilla verkossa: https://www.hs.fi/politiikka/art-2000002851061.html. Viitattu 14.10.2020.

HS 9.9.2015. HS. Reaktioita leikkauksiin: Myrkkyä, historiallista - ja välttämätöntä. Helsingin Sanomat. Saatavilla verkossa: https://www.hs.fi/ilta/art-2000002851165.html. Viitattu 14.10.2020.

HS 4.6.2016. Luukka, Teemu ja Niskakangas, Tuomas. Kilpailukykysopimus syntyi yli vuoden väännön jälkeen. Saatavilla verkossa: https://www.hs.fi/kotimaa/art-2000002904648.html. Viitattu 14.10.2020.

IL 8.9.2015. IL-STT. STTK: "Hallitus leikkii tulitikuilla ruutitynnyrin lähellä”. Iltalehti. Saatavilla verkossa: https://www.iltalehti.fi/uutiset/a/2015090820314854. Viitattu 14.10.2020.

IL 4.6.2016. Poutanen, Pauli. Rinne kiittelee ay-liikettä somessa - haluaa lupauksen hallitukselta. Saatavilla verkossa: https://www.iltalehti.fi/uutiset/a/2016060421676550. Viitattu 14.10.2020.

STT 8.9.2015. Luotonen, Anniina, Salminen, Viivi, Nikula, Sanna ja Jääskeläinen, Susanna. Kipeät työelämän kiristykset syntyivät ilman järjestöjäkin. STT.

STT 19.2.2016. STT. Järjestöillä ei mandaattia neuvotella pätkätöistä ja aikuiskoulutustuesta. STT.

STT 2.3.2016. STT. SDP:n Rinne: Ratkaisussa "epäviisaita ja epäoikeudenmukaisia asioita". STT.

STT 4.3.2016. STT. EK:n Häkämies: Tolkkua tarvitaan. STT.

STT 31.5.2016. STT. Takaraja oli ja meni - vääntö kilpailukykysopimuksesta jatkuu. STT.

Yle.fi 8.9.2015. Santaharju, Teija. SAK tyrmää ja Akava varoittaa tuhoamasta sopimista - STTK: "Hallitus leikkii tulitikuilla". Yleisradio. Saatavilla verkossa: https://yle.fi/uutiset/3-8290078. Viitattu 14.10.2020.

Yle.fi 28.9.2015. Yle Uutiset. Sipilä: Kätilöt käänsivät pääni. Yleisradio. Saatavilla verkossa: https://yle.fi/ uutiset/3-8338636. Viitattu 14.10.2020.

Yle 14.7.2016. Jokiniemi, Emmakaisa. Myös Rinteeltä kritiikkiä kokoomuksen sunnuntailisäesitykselle. Saatavilla verkossa: https://yle.fi/uutiset/3-9027697. Viitattu 14.10.2020.

Yle A-studio 16.9.2015. TV1, Yleisradio. 


\section{Viitatut sosiaalisen median päivitykset}

Rinne, Antti. 2.3.2016. Facebook-päivitys. Saatavilla verkossa: https://www.facebook.com/anttirinnepj/ posts/1746866538879966. [Viitattu 14.10.2020.]

Rinne, Antti. 3.6.2016. Facebook-päivitys. Saatavilla-verkossa: https://www.facebook.com/anttirinnepj/ posts/1786593601573926. [Viitattu 14.10.2020.]

Rinne, Antti. 14.7.2016. Facebook-päivitys. Saatavilla verkossa: https://www.facebook.com/anttirinnepj/posts/1803089693257650. [Viitattu 14.10.2020.]

\section{KIRJOITTAJATIEDOT}

\section{OLLI SEURI}

YTT, tutkijatohtori

Yhteiskuntatutkimus

Yhteiskuntatieteiden tiedekunta

Tampereen yliopisto

olli.seuri@tuni.fi

\section{RIIKKA ERA}

YTM, tutkija

Yhteiskuntatutkimus

Yhteiskuntatieteiden tiedekunta

Tampereen yliopisto

riikka.era@tuni.fi

\section{ANU KOIVUNEN}

FT, professori

Sukupuolentutkimus

Yhteiskuntatieteiden tiedekunta

Tampereen yliopisto

anu.koivunen@tuni.fi

\section{MACIEJ JANICKI}

TkT, tutkijatohtori

Digitaaliset inmistieteet

Humanistinen tiedekunta

Helsingin yliopisto

maciej.janicki@helsinki.fi 


\section{PIHLA TOIVANEN}

FM, tohtorikoulutettava

Digitaaliset inmistieteet

Humanistinen tiedekunta

Helsingin yliopisto

pihla.toivanen@helsinki.fi

JULIUS HOKKANEN

YTM, tutkija

Sukupuolentutkimus

Yhteiskuntatieteiden tiedekunta

Tampereen yliopisto

julius.hokkanen@tuni.fi

\section{EETU MÄKELÄ}

TkT, apulaisprofessori

digitaaliset inmistieteet

Humanistinen tiedekunta

Helsingin yliopisto

eetu.makela@helsinki.fi 